\title{
Ethnozoology of bushmeat
}

Importance of wildlife in diet, food avoidances and perception of health among the Baka (Cameroon)

Ethnozoologie de la viande de brousse: De l'importance de la faune dans le régime, les évitements alimentaires et la perception de la santé chez les Baka (Cameroun)

\section{Romain Duda, Sandrine Gallois and Victoria Reyes-García}

\section{OpenEdition}

\section{Journals}

\section{Electronic version}

URL: http://journals.openedition.org/ethnoecologie/3976

DOI: 10.4000/ethnoecologie.3976

ISSN: 2267-2419

\section{Publisher}

Laboratoire Eco-anthropologie et Ethnobiologie

\section{Electronic reference}

Romain Duda, Sandrine Gallois and Victoria Reyes-García, «Ethnozoology of bushmeat », Revue d'ethnoécologie [Online], 14 | 2018, Online since 31 December 2018, connection on 01 May 2019. URL : http://journals.openedition.org/ethnoecologie/3976 ; DOI : 10.4000/ethnoecologie.3976

This text was automatically generated on 1 May 2019.

\section{(9) $\odot \Theta \Theta$}

Revue d'ethnoécologie est mis à disposition selon les termes de la licence Creative Commons Attribution - Pas d'Utilisation Commerciale - Pas de Modification 4.0 International. 


\section{Ethnozoology of bushmeat}

Importance of wildlife in diet, food avoidances and perception of health among the Baka (Cameroon)

Ethnozoologie de la viande de brousse: De l'importance de la faune dans le régime, les évitements alimentaires et la perception de la santé chez les Baka (Cameroun)

Romain Duda, Sandrine Gallois and Victoria Reyes-García

\section{Introduction}

1 In the Congo Basin, food is an everyday concern and its acquisition and transformation often structure many of the activities of a human group (Bahuchet 2000). Agriculture provides the basis starchy food (calories), while forest products provide proteins and other important dietary elements such as micronutrients. The meat of wild animals, most commonly referred to as bushmeat, represents the main source of proteins for local people in this region (Froment et al. 1996, Bahuchet \& Ioveva 1999, Cawthorn \& Hoffman 2015) and plays an important role in terms of dietary diversity (Van Vliet \& Mbazza 2011) and health and wellbeing (Motte-Florac et al. 1996, Epelboin et al. 2012, Ichikawa et al. 2016, Van Vliet et al. 2017). 
Figure 1: Among the Baka, as many others wild animals, the terrestrial turtle (Forest hinge-back tortoise, Kinixys erosa) is an appreciated meat but its consumption is also regulated by specific avoidances

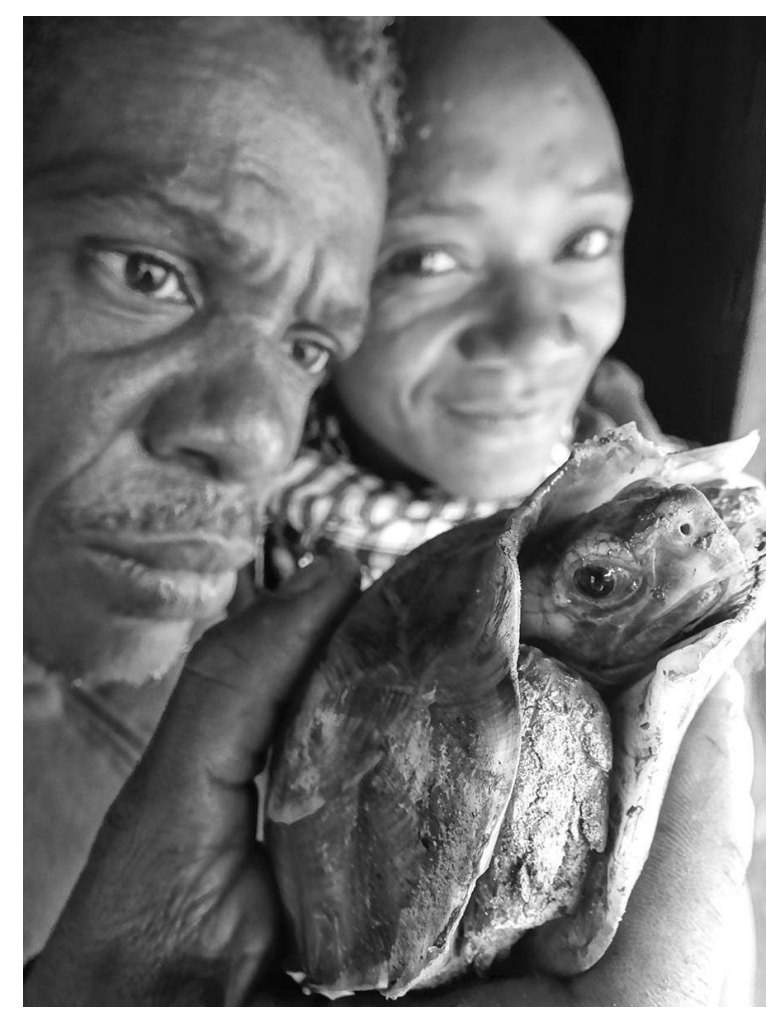

(c) R. Duda

Beyond local consumption, wild meat products are becoming an increasingly vital component of the regional and national economy, their commercialization becoming a growing source of income for forest population (Coad et al. 2010). However, the combination of an the increase in bushmeat consumption combined with the emergence of some more efficient hunting practices has pushed the harvest of wild animals to unsustainable levels, generating a "bushmeat crisis" (Nasi et al. 2008) that will undoubtedly threaten food security in the future (Fa et al. 2015). For instance, in Cameroon, the growing demand for bushmeat has fueled the lure of profit, creating strong pressures on all groups of the southern region, who currently engage in (illegal) bushmeat commercialization. As local populations become involved in bushmeat commercialization, cash income from the sale of wild meat becomes a non-negligible source of revenue, used either as a safety net (Van Vliet et al. 2010) or as a way to cover intermittent needs, such as school fees, parties, and funerals (Allebone-Webb 2008, Fa \& Brown 2009). However, this is not the case for all the populations. For instance, among the Baka, a hunter-gatherer group who have been facing several important social changes in the last sixty years, money earned from the sale of bushmeat is not really saved, but rather mostly spent on very cheap and low-quality alcohol (Oishi \& Hayashi 2014, Townsend 2015). Moreover, the commercialization of bushmeat might be affecting local diets in two different ways. First, it might be reducing the amount of proteins consumed by forest populations, as meat sold does not enter in the household diet; and second, it might lead tothe incorporation of new elements in the diet, as income from meat trade might be used to purchase new types of foods or to buy drink instead of food. 
Previous research has focused on different aspects of Baka food resources: the drivers of dietary diversity among adults and children (Reyes-Garcia et al. 2018, Reyes-García et al. in press); the adoption of agriculture and its impact on their social organization (Kitanishi 2003, Dounias \& Froment 2011, Leclerc 2012); the management of wild yams (Yasuoka 2009, Bahuchet 1991, Dounias 2001) and their dietary cultural norms (Joiris 1996). Overall, although work on other central African hunter-gatherer groups (so-called "Pygmies") groups allows some insights (Dounias 1987, Bahuchet 1988, Bahuchet 1990, Koppert et al. 1996), the specific role of bushmeat in Baka diet and income has not been specifically explored (except for Reyes García et al. in press). Moreover, the issue becomes pressing face to rapid changes: changes in hunting strategies (Duda 2017), local defaunation (Fa \& Brown 2009, Bobo et al. 2014), the increasing use of monetary exchanges (Kitanishi 2006, Oishi \& Hayashi 2014), and the transformation of their territory due to the creation, often without their prior consent, of logging concessions, national parks, wildlife reserve and trophy hunting territories (Pyhälä et al. 2016, Duda \& Gallois in press).

In this overall context of change, this paper takes an ethnoecological perspective to both explore the relation between the Baka and their surrounding wildlife and bring together the sociocultural values and the economic importance of meat.

5 After introducing the topic with a literature review, this paper develops the three interconnected components of wild meat for the Baka. First, we detail the social and cultural relevance of wild animals in Baka society through the existence of social norms regarding avoidances and preferences in meat consumption. In a second part, we draw an overview of how meat from different wild animal species is differentially consumed by individuals. Finally, we place wild meat in the broader local context of the economy of hunting and the bushmeat market, analyzing the way in which the Baka sell bushmeat and how this activity contributes to their economy.

\section{The cultural value of wild meat in the Congo Basin}

Wild meat is the most valued food in Central Africa in general (Ichikawa et al. 2016), and is highly appreciated, notably mammals, both in rural and urban areas and among all social classes (Nasi et al. 2011). Consequently, the transfer of wild meat from rural areas to cities is an important driver of the bushmeat crisis. Considered as a symbol of power and prestige, wild meat is highly demanded by city dwellers, who maintain a symbolic relation with the forest through wildmeat consumption (Ichikawa et al. 2016). Wild meat is also an element of prestige, notably for ruling classes who, in important meetings, might require the presence of this highly-valued meat, which sometimes include protected species illegally obtained. The symbolic status of wild meat slightly differs in rural areas, where it is more available. In these settings, wild meat is more associated with the relation between animals and forest spirits and the social norms of sharing

Bushmeat consumption also contributes to psychological wellbeing. Researchers have documented, in Central Africa, a qualitative modification of the diet along the year with a psychological trauma corresponding to periods characterized by "meat hunger" (Thomas et al. 1981-2014, Pagezy 1982, Bahuchet 1985, Garine \& Pagezy 1990). In southeastern Cameroon, every group has its own term to refer to "meat hunger": kbokaku among the Bangando (Kimura et al. 2012), zoo among the Bakwelé (Oishi 2014), and pene among the Aka and the Baka (Bahuchet 1992, Brisson 2010). In this context, "meat hunger" is a phenomenon linking culture and physiology, through which the cultural perception of 
lack of meat negatively influences wellbeing by generating stress, tiredness, or depression (Pagezy 1982, Garine \& Pagezy 1990).

\section{Meat avoidances among Central African hunter-gatherers}

8 Food avoidances have been studied among different groups of the Congo Basin (e.g., the Mbuti, the Efe, the Aka, and the Baka), and it has been shown that several avoidances are widely shared (Ichikawa 1987, Terashima 2001, Takeuchi 2013). The consumption of certain wild animal species is often symbolically associated with severe illnesses (Garine \& Hladik, 1989). Indeed, most food avoidances refer to wild animals and highlight the power of animals over human health and reproductive capacities, but also over hunting success and social life in general.

Among the Baka and the Aka, meat avoidances are referred to through the notion of kìà (sing: è.kìlà / plu.: bè.kìlà) ${ }^{1}$ (Bahuchet 1985, Thomas et al. 1981-2014, Lewis 2008, Epelboin et al. 2012), a term that is synonymous to the notion of kuweri among the Mbuti (Ichikawa 1987). Principally centered on meat avoidances ${ }^{2}$, the concept of kilà allows the establishment of a complex system of individual and group care (Motte-Florac et al. 1996), having both positive and negative aspects (Lewis 2008). Animals have more or less strong kilà that may affect humans accordingly (illness, bad luck). One might recourse to the concept of è.kìlà a posteriori to explain something wrong that happened, or kilà might be a reason not to eat an animal, anticipating thus a harmful effect. In general, the threats pose by animals depend two main aspects that are interconnected in this concept of kilà: the characteristics of the animal and the characteristics of the consumer. As in several hunter-gatherer groups, such avoidances are based on a metaphoric or metonymic logic relative to animals' phenotypical or behavioral attributes (Levi-Strauss 1962), but are also related to specific characteristics of the potential consumers including their life stage (notably reproductive life), activity (notably hunting), or biophysical state (such as pregnancy).

10 Thus, avoidances can be either temporary or permanent, and although only few animals are systematically refused, most animals considered as "edible" might be avoided by someone at some point (Bahuchet 1985, Ichikawa 1987, Motte-Florac et al. 1996). Nothing being totally socially constructed and fixed, but evolving through individual interactions with animals and collective experiences (Lewis 2008). Still connected to the concept of kilà, some avoidances relate not on a specific species but on its context of acquisition: for instance the young hunter cannot eat the first animal he killed with a spear, and the master of elephant hunting cannot eat any part of the pachyderm he slaughtered.

\section{Diversity of practices for meat acquisition}

11 If the consumption of animals depend on preferences and avoidances, it also depends on the type of hunting techniques chosen. Baka's hunting strategies currently used in the studied area are diverse and depend on individual's age, gender, personal preferences, and level of integration into the market economy (Duda et al. 2017). Hunting practices are learnt by children themselves at early ages through a collective amusement allowing them to acquire small but non-negligible amount of proteins (Gallois 2015, Gallois et al. 2018). Male adolescents rapidly perform hunting in small group to provide meat for the family ${ }^{3}$ (Figure 2). Moreover, although hunting is usually considered as a male activity, 
the activity is not exclusive at all, and women might hunt either in the absence of men, or with them (in couple), either opportunistically or voluntary.

Figure 2: Adolescents after having caught a brush-tailed porcupine by smoking the animal's hole

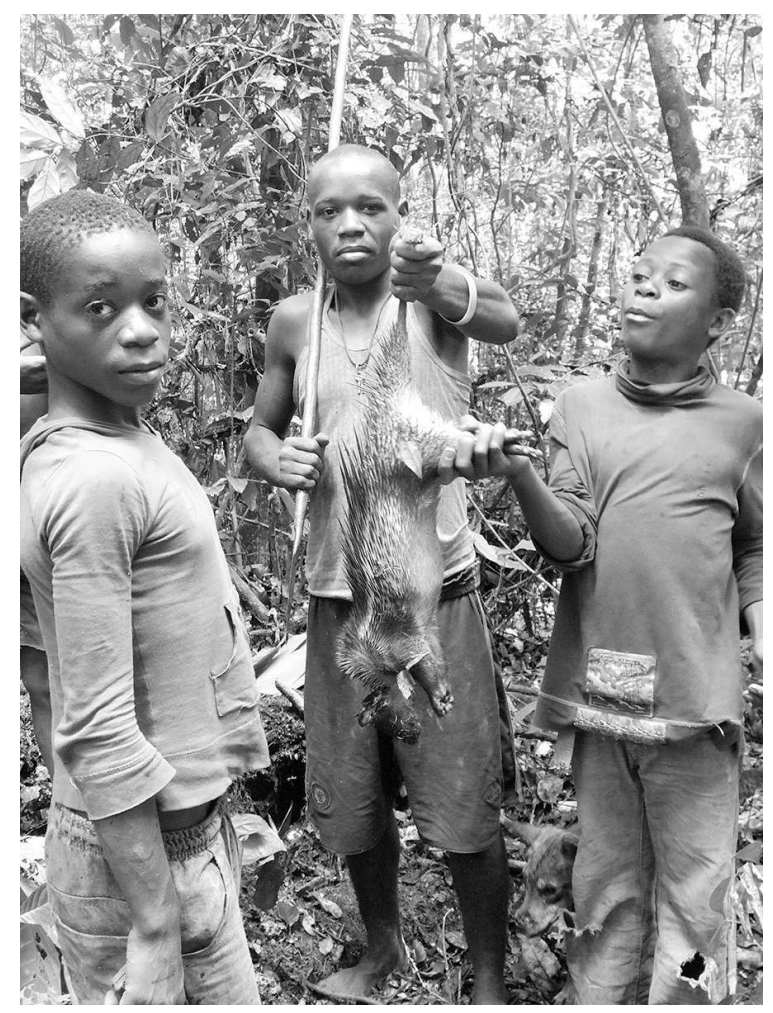

(c) R. Duda

12 Although the Baka have traditionally relied on a diversity of hunting techniques depending on social, seasonal and ritual circumstances, they were mainly considered as spear hunters (Figure 4). The use of spear took diverse forms: it was used for collective hunting targeting large-mammals (i.e., elephant, gorilla, and hogs) ${ }^{4}$, or coupled with the use of a dog to corner small duikers and rodents. The adoption of a more sedentary lifestyle has had a non-negligible impact on hunting strategies for the Baka, who now use more individualistic techniques, such as snares and shotguns, with the consequent reduction of collective hunting (Duda et al. 2017). Snare trapping with metallic cables (Figures 6 and 7) and shotgun hunting (Figure 8) are currently the two most productive and used techniques. Trapping is nowadays known as the main hunting technique used by the Baka (Hayashi 2008, Yasuoka 2014), combined with the increasing use of shotguns (Kitanishi 2006, Hayashi 2008). Digging out porcupines with fire or Emin's pouched rats with machetes and dog are also very common techniquesb (Figures 9,10 and 11). The use of crossbow, introduced by Portugeses in the $16^{\text {th }}$ century and which is not a typical Baka technique (Bahuchet 1992, Dounias 2016) remains very rare. 
Figure 3: List of animal and plant species mentioned in the study

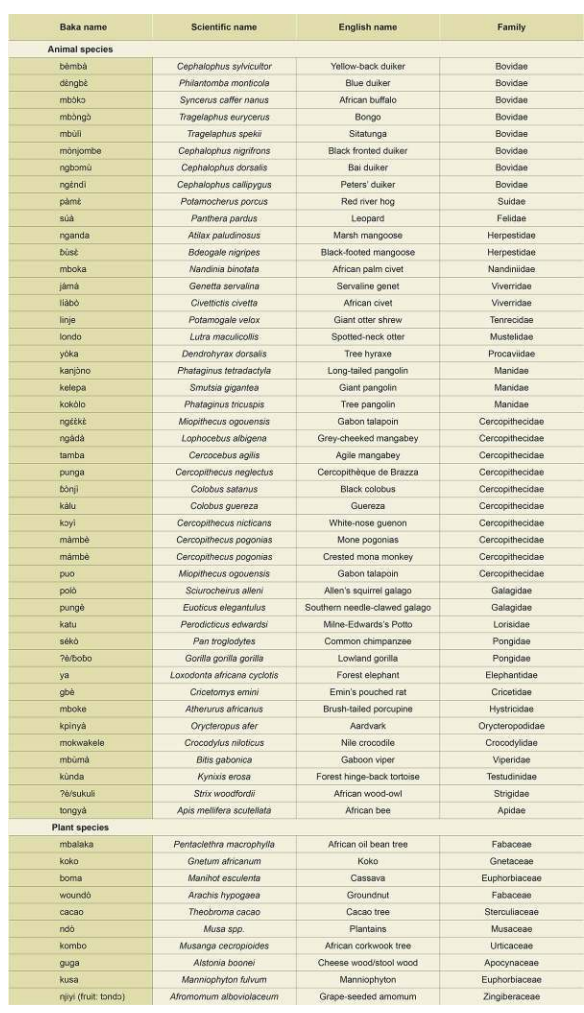

Figure 4: Baka spear made with an old machete

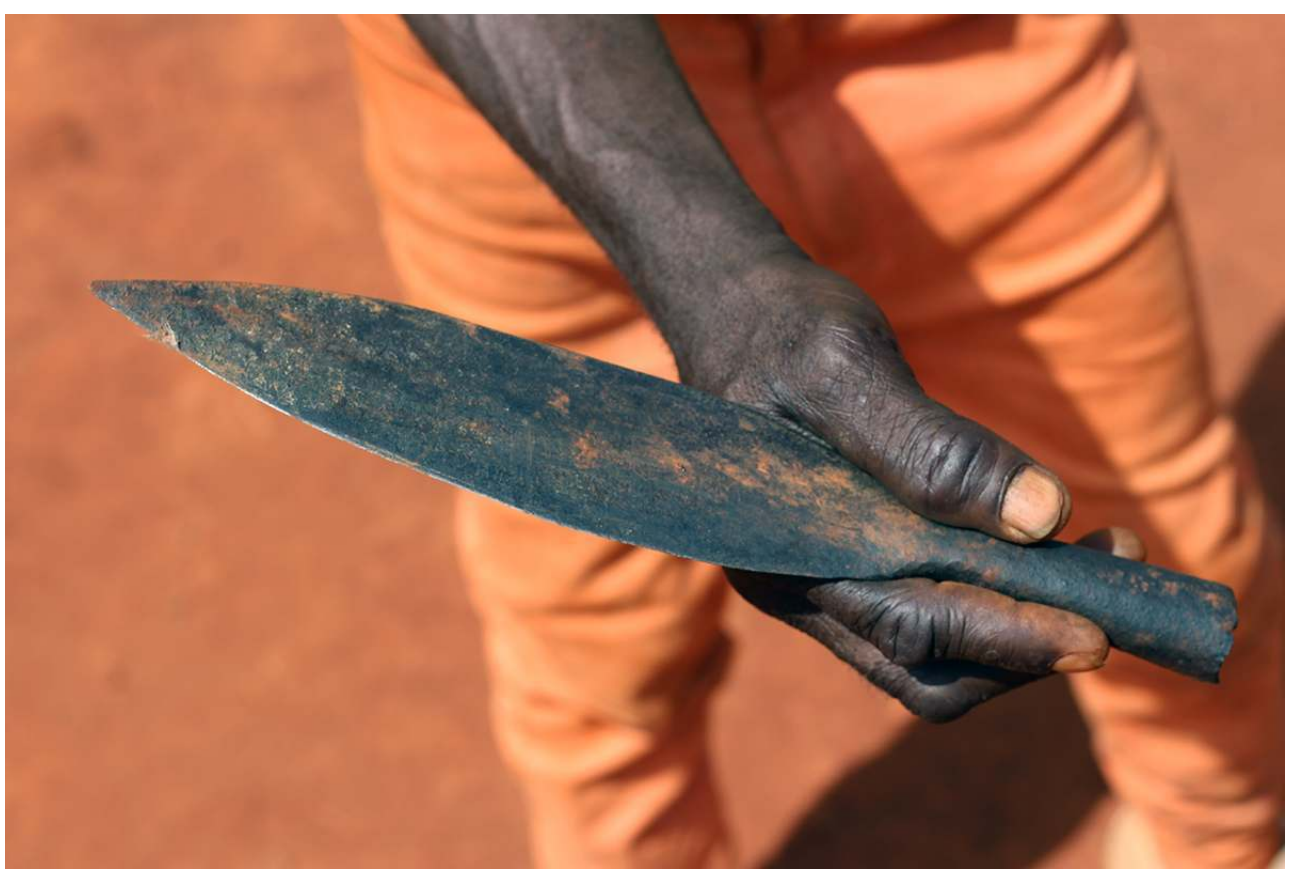

(c) R. Duda 
Figure 5: Mice trap made by children with vegetal materials

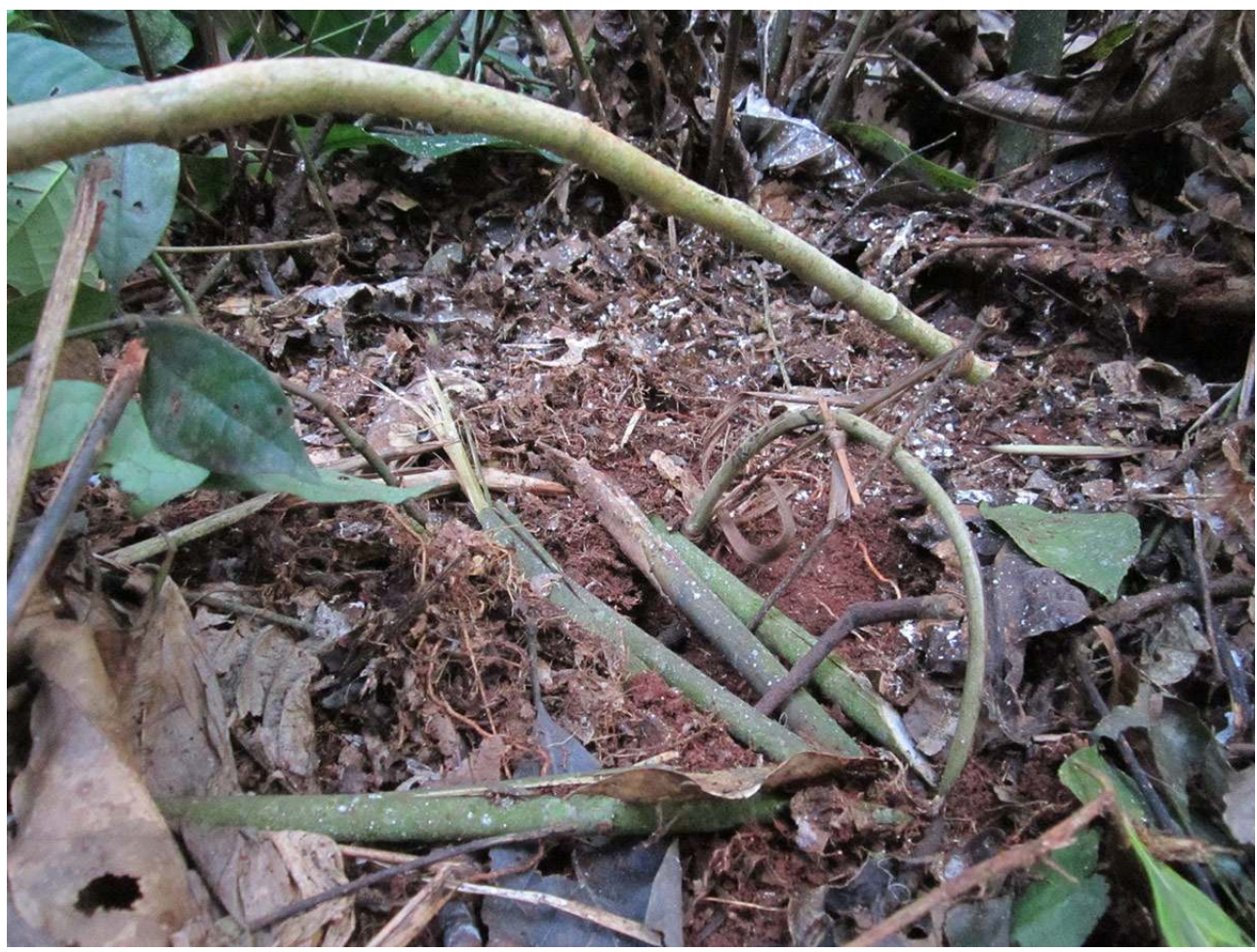

(c) R. Duda

Figure 6: Leg-hold snare trap made by adults with twisted metal cable (here the most common setting: ANJASSI)

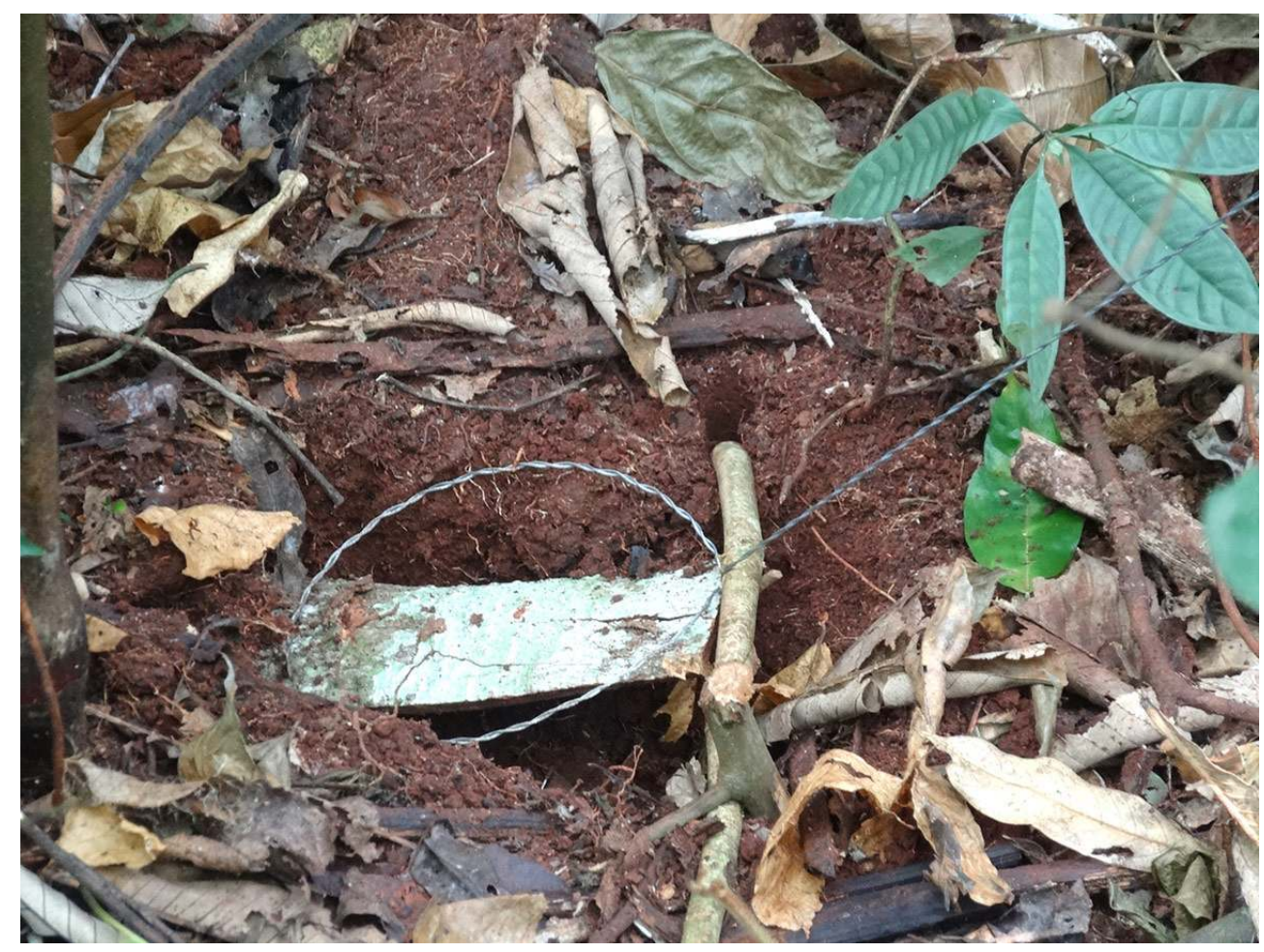

(c) R. Duda 
Figure 7: Neck snare trap made with twisted metal cable (second most common setting, neck snare: A PE KU.LO)

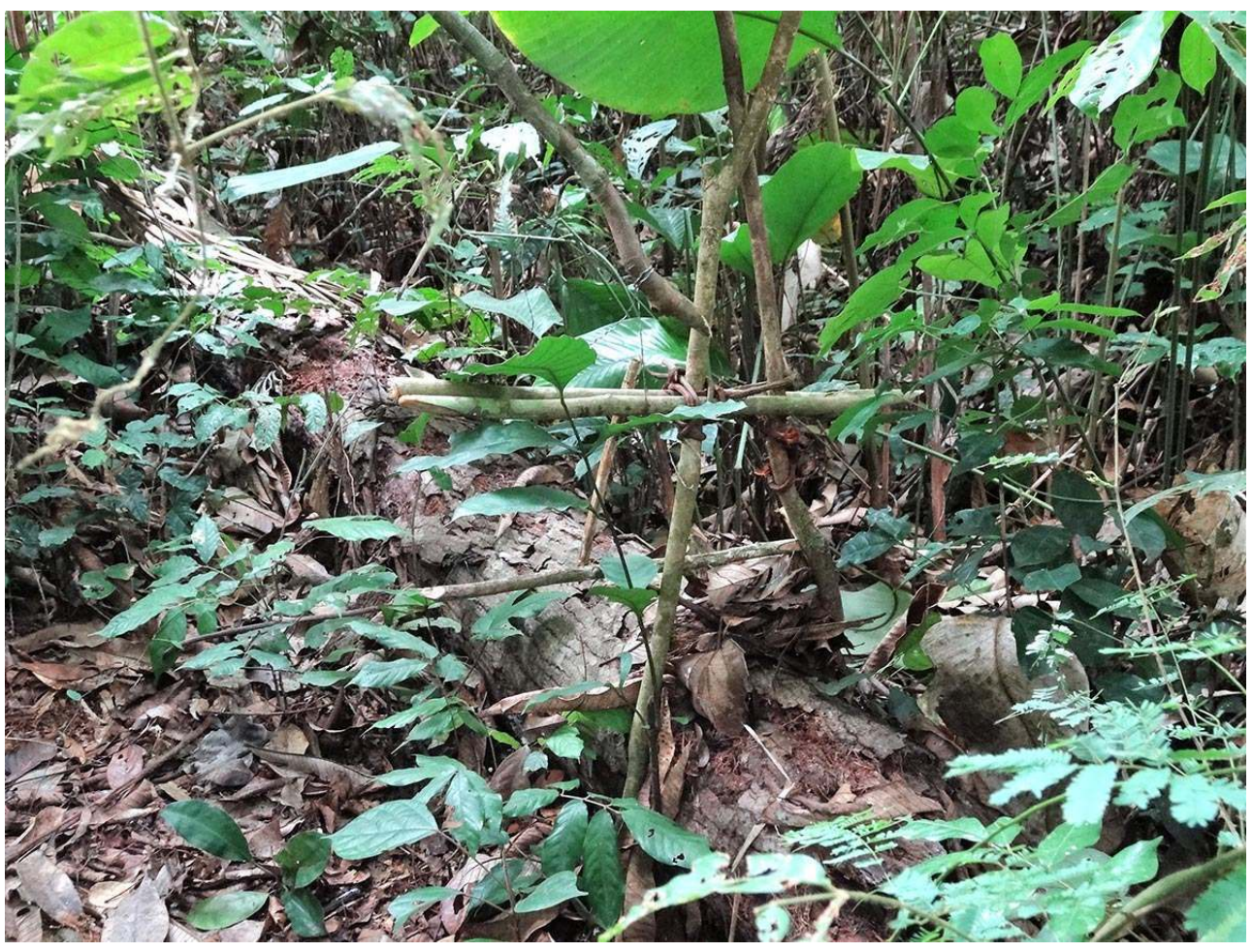

(c) R. Duda

Figure 8: 12 gauge shotgun belonging to an Nzime but used by Baka hunters

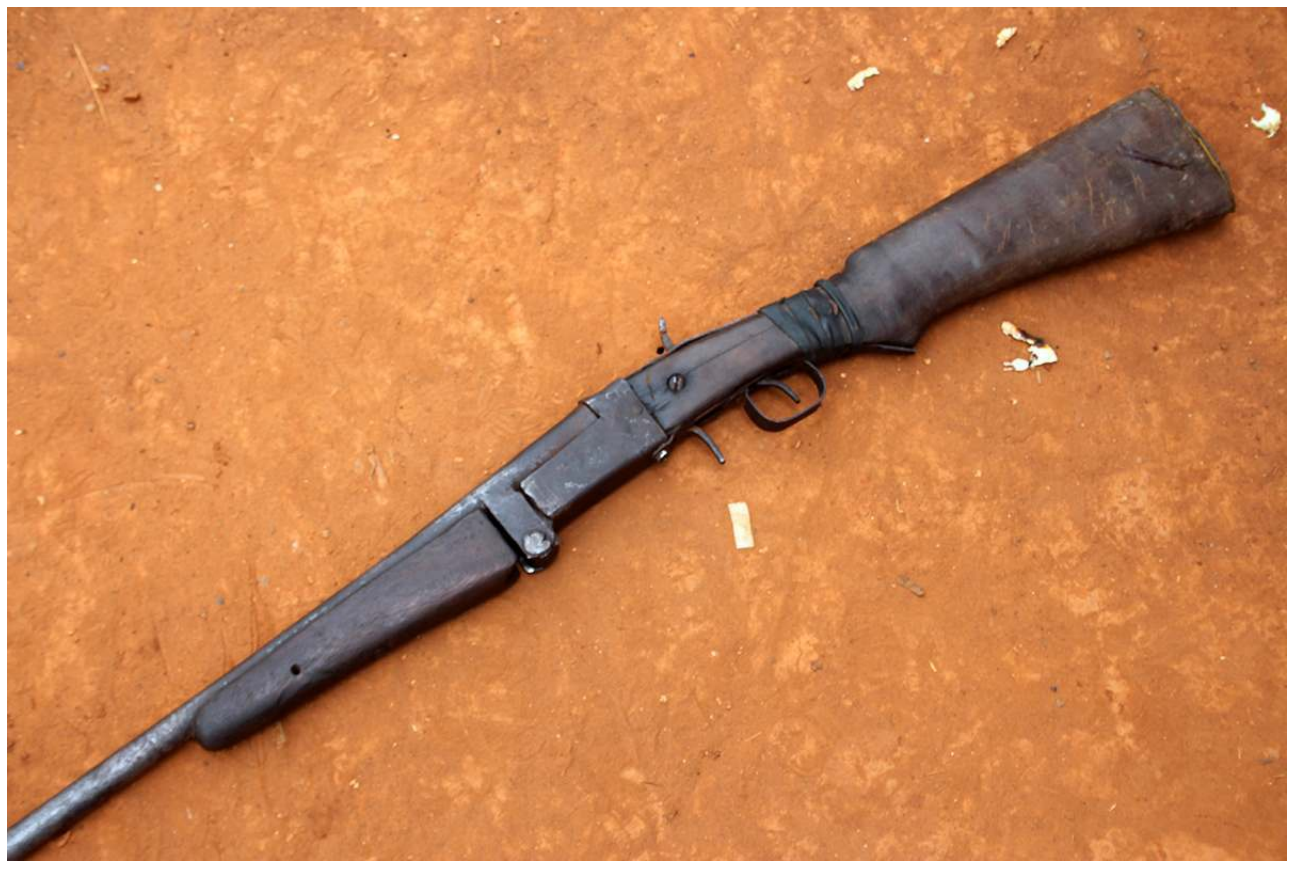

(c) R. Duda 
Figure 9: Baka man smoking a fallen hollow tree where a brush-tailed porcupine (Atherurus africana) is hiding

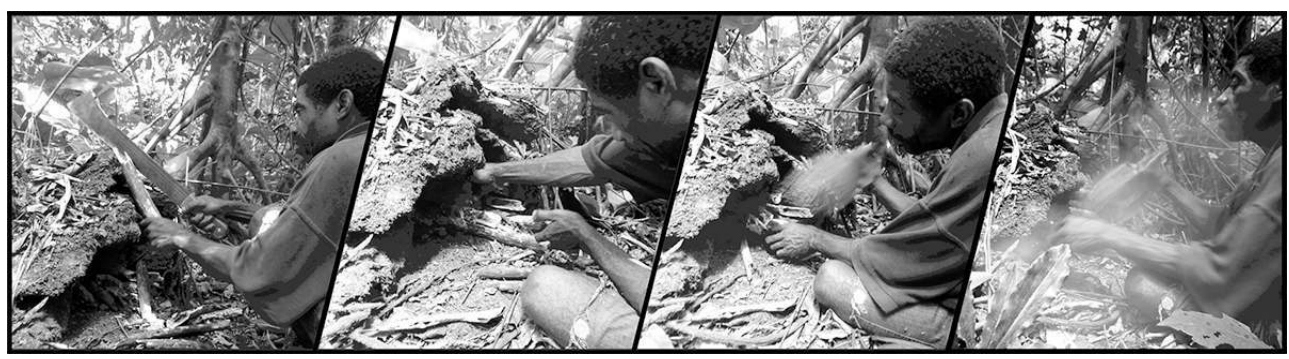

(c) R. Duda

Figures 10 and 11: Holes dug to excavate Emin's pouched rat (Cricetomys emini)

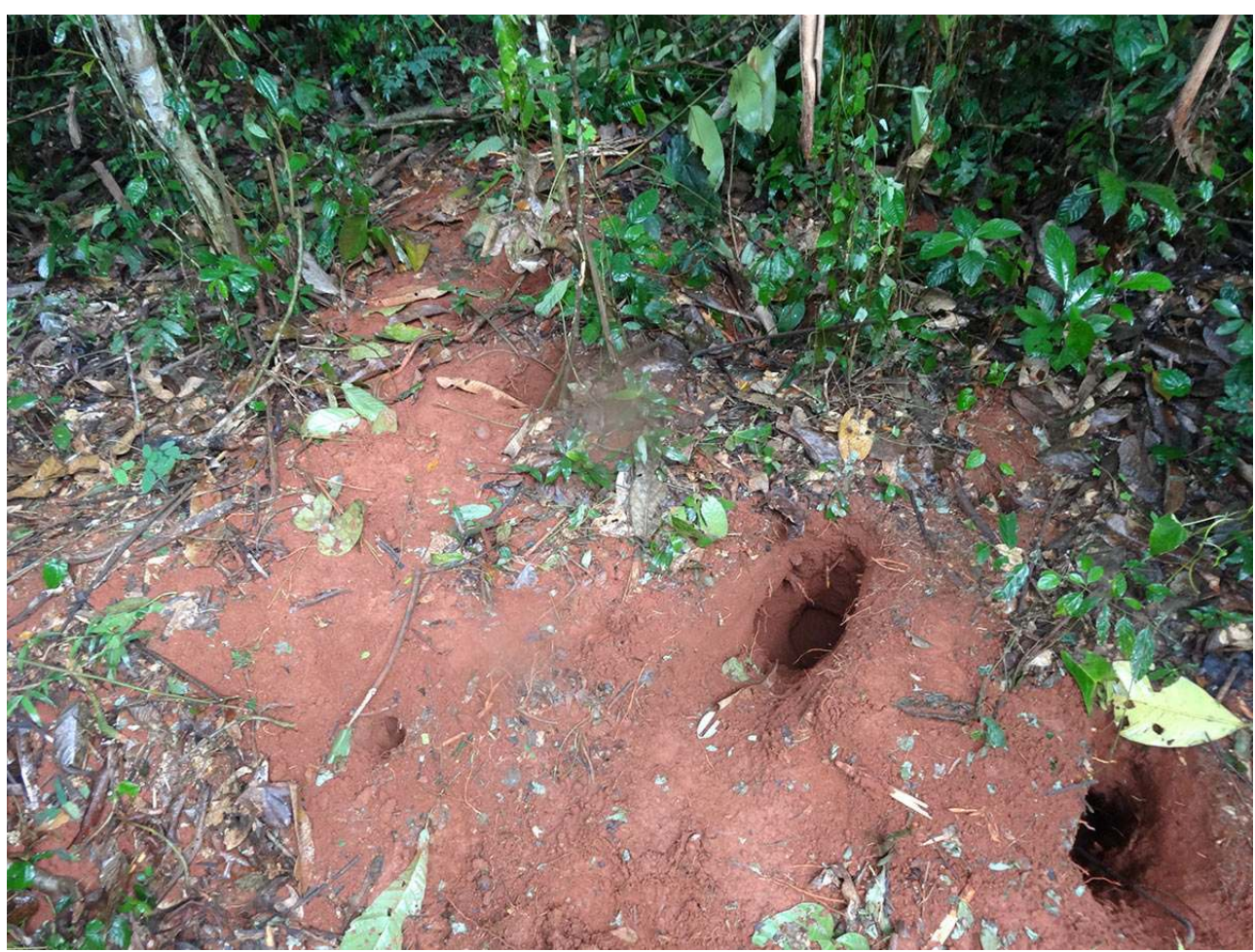




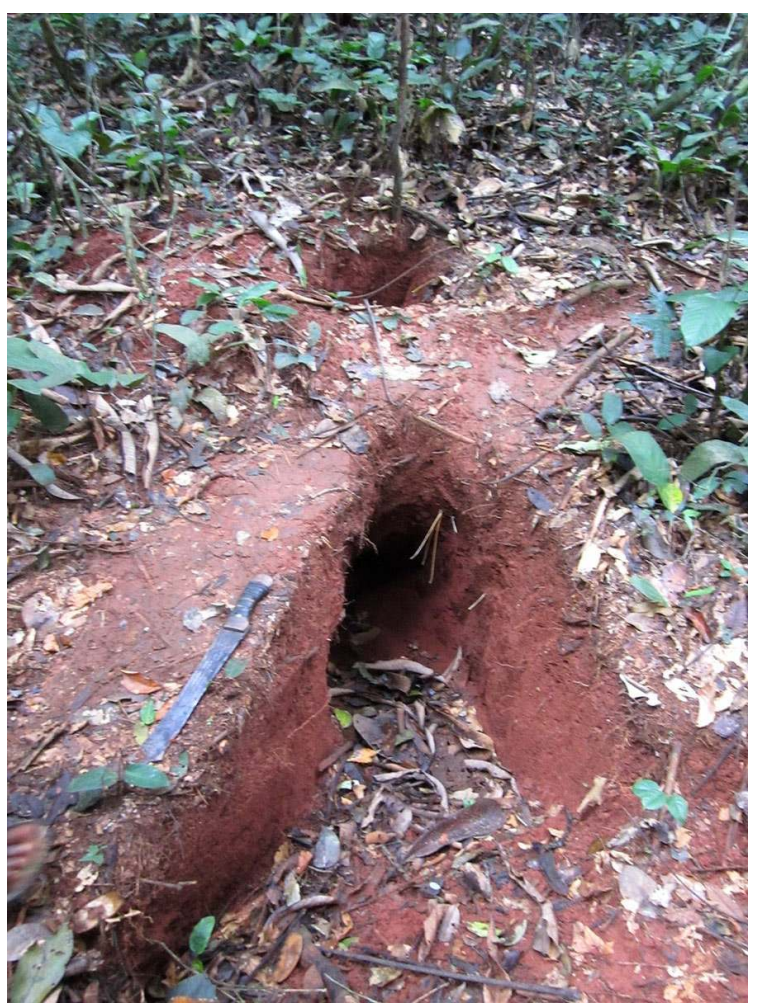

(c) R. Duda

Figure 12: Basket used by men to carry wild game (LIKULÉ)

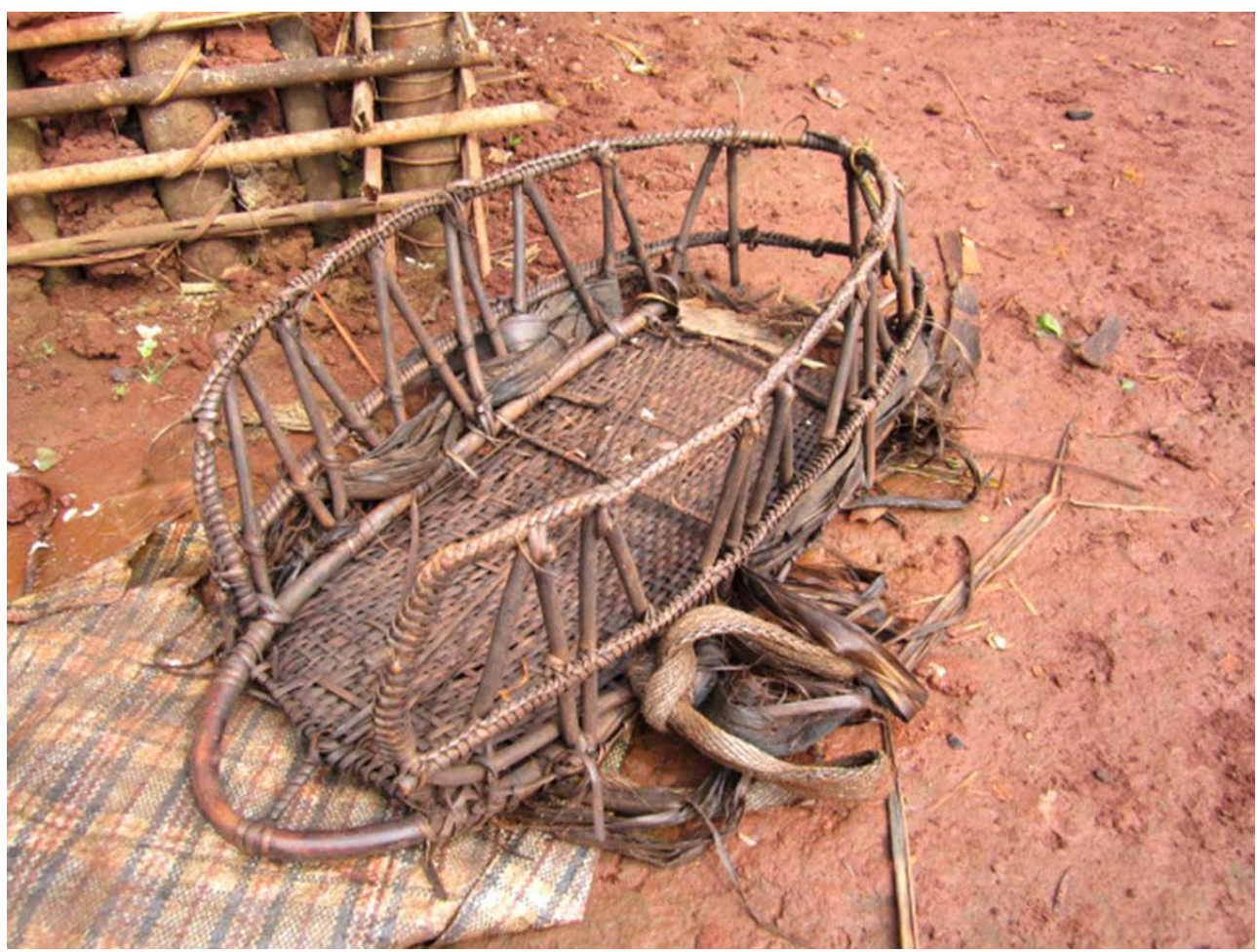

(c) R. Duda

13 Elephant hunting is one of Baka archetypical hunting practices and has been considered as the hunt by excellence (Bahuchet 1992). However, elephant hunting is performed by a 
specific category of hunters: the tuma. Elephant hunting, like all hunts of large mammals, requires specific social and technical organization (Joiris 1998), and carries the highest social and symbolic importance, although smaller and less ritualized hunts are of primary importance for daily food supply (Bahuchet 1992). In the Baka emic system, elephant hunting has been widely described through the lens of the mythological and spiritual relations between humans and elephants (Joiris 1996, Kölher 2000). Although elephant meat is highly appreciated, it is especially the symbolic aspect of its hunt, the quantity of meat, and the specific relation between elephants and forest spirits that gives to this activity a great cultural and social importance. Supplying more than one tone of meat per animal (Fargeot 2013), killing an elephant represented a festive event of uncommon sharing, which allows forming a tight-knit group (Leclerc 2006). Nowadays, Baka elephant hunters are frequently employed to hunt elephants by their neighbours, foreign traders (from West and North Cameroon), and officials or soldiers interested in the lucrative ivory, trade from which the Baka do not benefit (Duda \& Gallois in press).

\section{Methods}

\section{Research Settings}

This research took place among several Baka communities in southeastern Cameroon, located in the districts of Lomié and Messok, in the Haut-Nyong Department. In this area, Baka people are living in close relation with the Nzime, a Bantu speaking group whose livelihood is based on slash-and-burn agriculture. Most data were collected in two communities (referred here as MB and EL), with an approximated population of 300 individuals (with children), where the two first authors were settled during 18 months (between February 2012 and June 2015). Before data collection started, we firstly obtained the free prior and informed consent (FPIC) from villages and individuals participating in the study. This study adheres to the Code of Ethics of the International Society of Ethnobiology and received the approval of the ethics committee of the Universitat Autònoma de Barcelona (CEEAH-04102010).

\section{Interviews and observation}

Results presented in this paper combine both qualitative and quantitative data. Information comes from structured, semi-structured and informal interviews conducted among Baka men and women, as well as from participant observation. Specifically, the first author conducted semi-structured interviews to gather information on meat avoidances and preferences. These interviews consisted in asking 20 people to report any animals they personally refuse to eat and the reasons why. The open question was asked as follows: "What are the game you personally don't eat?"'. Once the person finished listing, for each animal reported we asked "why you don't eat X?" We specifically asked about animals "that you don't eat" rather than about animals "that the Baka do not eat" to obtain a more personal appreciation of the relation between the concepts 'animal' and 'meat'. We also asked about meat preferences using the question "Which game do you prefer to eat?" Saliency Index to examine the significance of each species through their occurrence. 
Finally, the first author also interviewed 10 hunters regarding their implication in local meat trade, market exchanges, their way of selling, bushmeat local prices, seasonality of trade, and how they used money received from bushmeat selling. During fieldwork, particular attention was put on bushmeat cooking and consumption. Data were obtained notably through open discussions but also by observation of animal butchering, meat sharing, and practices associated with specific species or animal parts. These observations were sometimes video recorded ${ }^{7}$.

\section{Data collection}

17 From August 2012 to August 2013, we collected dietary diversity data twice a quarter of year (twice each three months period). We asked each adult in the sample to report all the food items eaten the day before the interview, from the first thing consumed in the morning to the last thing consumed before sleeping. After having obtained the information related to the two main meals, we asked them to recall any small amount of food consumed between meals (e.g., fruits, seeds, drinks, alcohol, or sweets). We also asked them to name the condiments included in the meals (e.g., chili, salt, aromatic). We did not ask about the quantities, but we recorded whether the food items originated from sharing, or from the market (bought or bartered). For each meal that included meat, we asked them to report the animal species (vernacular name) $)^{8}$. Although we recorded all food items consumed, for the scope of this research we only analyze animal products (see Reyes-García et al. 2018 and Reyes-García et al., in press for a wider overview).

18 To obtain data about wildlife offtakes, we conducted weekly recalls on a day chosen at random during one year. We asked to each individuals of the sample to report the animals they have hunted or collected in the two previous days (see Duda et al. 2017 for more details).

Data consisted of 1326 days of self-reported data collected among 266 adults ranging from 16 to 75 years of age (mean 34.8 years). Among them, we recorded data for 149 women and 117 men, with an average of five self-reported recalls per individual. We calculated the share of days that an individual consumed meat from the total number of days the person was observed. We did the same calculation for fish for comparative purposes. To have an estimation of meat consumption according to age, we generated seven age categories (16-24: $n=69,25-34: n=83,35-46: n=47,45-54: n=30,55-64: n=24$, and 65 years old and above: $\mathrm{n}=13)$. Meat consumption was also analyzed according to seasonality. As hunting and fishing are highly gendered among the Baka (Gallois \& Duda 2016, Duda et al. 2017), we analyzed the share of meat and fish in diet separately for men and women. According to the date of the interviews, each self-reported recall has been assigned to one of the four locally determined seasons (see Figure 13). 
Figure 13: Percentage of days on which meat was consumed, by season. 490 interviews were realized during the major rainy season, 385 during the major dry, 375 during the minor rainy and 76 during the minor dry season

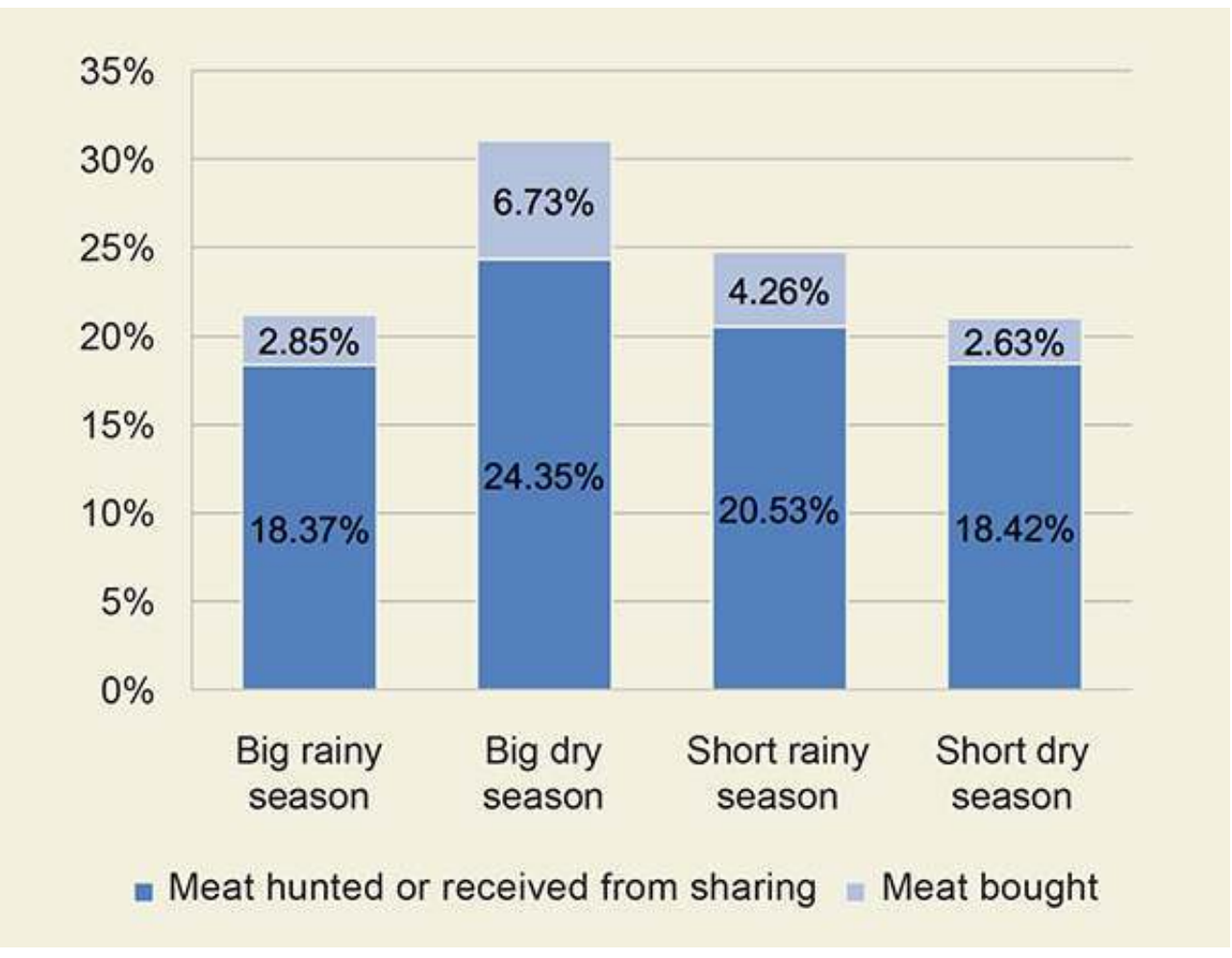

We also collected data on cash income obtained from the sale of products, including game. Every three months, we visited each household and asked each adult about all revenues from selling obtained in the two weeks prior to the interview, and the description of the products sold (e.g., what species). We asked informants to report the value of each product sold, and aggregated the value of products into the following categories: bushmeat, wild plants (e.g., seeds, leaves), crops (e.g., plantain, cassava, cacao), ivory tusks and pangolin scales, traditional items (e.g., baskets, axes, mats), modern items (e.g. alcohol, cigarettes), domestic animals (e.g., puppies, hens), honey and mushrooms.

\section{Commented Results}

\section{The socio-cultural components of bushmeat consumption: Avoidances and preferences}

21 In this section, we describe and examine the social and cultural components of wild meat as part of the Baka diet by focusing on two criteria that might possibly affect diet composition: (1) meat avoidances and (2) personal preferences regarding meat consumption.

\section{A juxtaposition of avoidances}

The Baka consume most animal species they can find in the forest, except for nocturnal birds and the leopard. However, most edible species may also be subject to avoidances. 
The literature about other "Pygmy" groups (Thomas et al. 1981-2014,Terashima 2001, Lewis 2008), describe on one side temporary avoidances, mostly related to reproductive, health status, or hunting activity and often link reproductive activities/life with animal transmitted illnesses. On the other side, permanent avoidances related to the lineage totemic identity are mentioned. Lacking studies on these aspects for the Baka, this section analyses the different forms of avoidances co-exist within this group. Figure 14 lists the species reported by the interviewees as generally avoided.

Interestingly, the most avoided species are the two apes, chimpanzee and gorilla (see section below), followed by a wide diversity of species, from buffalo to otter and crocodile.

Figure 14: Ranking of avoided species and reasons for avoidance

\begin{tabular}{|c|c|c|c|c|c|c|c|}
\hline Rank & English name & Baka name & Number of report & Smith Index & $\begin{array}{c}\text { Principal reasons of } \\
\text { avoidance }\end{array}$ & $\begin{array}{l}\% \text { of catches in hunting } \\
\text { survey (12 months) }\end{array}$ & $\begin{array}{l}\text { Class in national } \\
\text { hunting regulation }\end{array}$ \\
\hline 1 & $\begin{array}{l}\text { Common } \\
\text { chimpanzee }\end{array}$ & seko & 11 & 0,405 & $\begin{array}{l}\text { semi-human } \\
\text { appearence }\end{array}$ & 0 & A \\
\hline 2 & Lowland gorilla & ebobo & 7 & 0,263 & $\begin{array}{l}\text { semi-human } \\
\text { appearence }\end{array}$ & 0,35 & A \\
\hline 3 & Domestic pig & $\begin{array}{c}\text { pame na } \\
\text { gba }\end{array}$ & 6 & 0,221 & $\begin{array}{c}\text { domestic / eat human } \\
\text { wastes }\end{array}$ & (domestic) & I \\
\hline 4 & $\begin{array}{c}\text { Yellow-back } \\
\text { duiker }\end{array}$ & bemba & 5 & 0,158 & bad smell & 0,52 & A \\
\hline 5 & Aardvark & kpinya & 5 & 0,153 & $\begin{array}{c}\text { "bad animal", skin like } \\
\text { human }\end{array}$ & 0 & A \\
\hline 6 & Servalin genet & jama & 3 & 0,038 & bad smell & 0 & B \\
\hline 7 & African buffalo & mboko & 3 & 0,083 & bad smell & 0 & B \\
\hline 8 & $\begin{array}{l}\text { Spotted-neck } \\
\text { otter }\end{array}$ & londo & 3 & 0,088 & bad smell & 0 & C \\
\hline 9 & $\begin{array}{l}\text { Blackfooted } \\
\text { mangoose }\end{array}$ & buse & 2 & 0,027 & $\begin{array}{l}\text { bad smell + } \\
\text { resemblance to dog }\end{array}$ & ? & C \\
\hline 10 & Bosmans potto & katu & 2 & 0,05 & $\begin{array}{l}\text { bad smell + illness if } \\
\text { pregnant or new born }\end{array}$ & 0 & A \\
\hline 11 & Gabon talapoin & kema na ngo & 2 & 0,07 & $\begin{array}{l}\text { illness if pregnant or } \\
\text { new born }\end{array}$ & 0 & B \\
\hline 12 & Nile crocodile & mokwakele & 2 & 0,058 & cause illness & 0 & A \\
\hline 13 & All owls & esukuli & 2 & 0,088 & "bad animal", sorcery & 0 & C \\
\hline
\end{tabular}

Representations of illness transmission by eating meat: pregnancy and vulnerability of new-borns

Animal are sometimes obsviously related to illness as names of illnesses often refer to "illness of the [name of the species]", e.g., kò na kùnda (illness of the turtle). Given that the consumption of animals might be a threat for human health and at the origin of specific illnesses, meat of some animals is eaten with prudence and anxiety.

Figure 14 presents animal species reported as generally avoided by interviewees. Many Baka also invoke disgust and/or a refusal of certain animals due to the bad smell of the animal itself or its meat. In fact, surveys, informal interviews, observation in forest let appear that olfaction is central in the way the Baka sensitively interact with animals and forest in general. Human smell can make flee animals ${ }^{9}$ (Duda \& Gallois, in press), while human have aversion with some animal smell. Indeed, the Baka consider that an animal that have a strong odour might be a source of kilà and cause illness, even through aerial contamination. Beyond the real smell of the refused species, the attribution of bad smell might appear here as a form of stigmatisation of an animal to justify an avoidance.

In general, temporal avoidances are hallmarks in individual life stages and collective life. For example, many temporary avoidances concern young couples in reproductive age, 
more specifically between pregnancy and the end of weaning, as well as the fetus or newborn. Walking children and postmenopausal couples are less subject to meat avoidances. Among the trio husband/wife/new-born, the new-born is considered the most vulnerable and thought not to have enough strength to eat certain wild meat. People who are not in reproductive age and sexual life anymore are considered the least threatened by the potential danger of meat-eating, so they eat almost all species.

Interestingly, the avoidance system is flexible. Everyone is free to respect or not these preventive avoidances and all are aware that transgressing them only implies a risk for the individual, the couple, or the child. Arrangements with such loose social norms can always be found. For example, similarly to the Aka (Thomas et al. 1981-2014), the Baka often prepare remedies to treat illnesses attributed to the wild-meat consumption, mostly using a piece (bone, skin, feathers) of the species that has caused the illness.

Avoidances resulting on kilà are often related to behavioral or morphological analogies between the animal and the illness's symptom, following a metaphorical causality. Thus, eating an animal with spotted skin, such as the genet, might cause skin problems in children. Similarly, eating a crawling animal might cause problems in learning how to walk. These principles of analogy also apply to hunters' behaviors and techniques. Thus, for instance, problems during childbirth might be explained by the consumption of an animal trapped in a neck-snare. By the same principle, during his wife's pregnancy, a hunter should not introduce his hand into the nest of a hornbill, as in doing so he breaks the mud wall made by the male hornbill to enclose the female during brooding, which the Baka relate to problems during childbirth or abnormalities in the baby ${ }^{10}$. Indeed, the Baka see a causal link between parents' behaviors and childbirth and babies' wellbeing, a link that they attribute to the fact the foetus or the new-born might imitate or copy some behaviors. The following example provided by a Baka man supports this idea:

"When the baby is in the belly of the mother he/she is able to see everything and he/she mimics it. That is why the rat has to be pulled out of its hole by the head and not by the tail, otherwise the baby will see that and will come out in the wrong position during delivery » [A.S., male, 37 years old, MB village].

\section{Apes: "complicated meat"}

Half of the 20 individuals interviewed about food avoidances reported that they did not eat chimpanzee or gorilla, or both. However, this avoidance is not a strict social norm, as other members of the community (including elders and youngsters, men and women) referred to these animals as their favorite meat (Figure 25). Contrarily to the case for most other mammals, no illness seems to be attributed to chimpanzee or gorilla (Sato 1998; author's observations). Rather, people who refuse to eat apes invoke these animals' propinquity to humans, stating they are person-like both in shape and behavior. Talking about the chimpanzee, some Baka reported that it has « hands like humans » or " the same skin as humans». Moreover, the Baka consider the gorilla and the chimpanzee to be as clever as humans, being able to use tools and even to lure, trick, and attack humans.

Apes are clearly distinguished by the Baka from their category kema which includes all the monkeys, and tend to be classified into an unnamed category, although sometimes groups under the category so na susu (animal with hair). Moreover, compared to many other mammals, apes are not related to potential illnesses transmission to humans (Sato 1998). 
apes are linked with humans because of behavioral and morphological similarities more than any other species. As for many societies of northwestern Congo Basin, for the Baka the gorilla and the chimpanzee are considered special animals because they are thought to be related to humans through reincarnation. Such folk theories also reflect social changes of the two past centuries and have been influenced by outside agents (Giles-Vernick \& Rupp 2006). Indeed, the Baka believe that a Baka might reincarnate into chimpanzee after death, and an Nzime can reincarnate into a gorilla (see also Köhler 2005 and Oishi 2013 for the same observations among the Baka and other bantu-speaking groups). This is also seen in the fact that both groups use the terms "gorilla" and "chimpanzee" to represent each other negatively in a mocking manner.

Interestingly, that a person refuses to eat apes does not necessarily mean that the person will not kill them.

"I do not eat chimpanzee nor gorilla; they can be humans, you never know. When I killed a chimpanzee, I ate the intestines and sold the flesh to the Nzime. Sometimes when a person dies, before the body is buried, the person becomes a chimpanzee and flees into the forest. I saw that already ». [V.K. 46 years old, MB village]

Gorilla and chimpanzee hold indeed an ambivalent position in Baka ontology, as Oishi (2013) says that gorillas are "active actors that sometimes intervene in people's actual social relationships", interactions between humans and apes being bi-directional, apes constantly crossing the interspecies boundary between humans and animals.

Other animal species are also avoided because of the similarities of their physical attributes to humans. For example, the consumption of the aardvark is reportedly avoided because its skin's texture looks like human's one (pale yellowish-grey with short hair). Similarly, consumption of mongoose is sometimes refused owing to this animal's resemblance to the dog. Some people also refuse to eat birds whose singing reminds them of the human voice, such as parrots, because of their supposed relations with spirits.

\section{Illnesses and kilà as personal "allergies"}

As previsouly said, the concept of avoidance kilà is not equally shared and adopted within the community, it is also the result of personal experiences. For example, some adults refuse to eat a certain animal species because they did not eat this meat during childhood. They consider that this consumption might generate illness in a form of symbolic rejection, such as vomiting. Indeed, after weaning, most parents give to their children a large diversity of meat to seek for specific reactions between the child and the meat of different animals, and this consumption of animals during childhood is considered to create a symbolic immunity. Early interactions with animals, even though a simple act of consumption, is then stimulated to ensure good health and balance humans and animals. Someone who gets sick might call for kilà to explain the illness by the absence of such a "reaction test" during childhood, by the fact of not having eaten this meat during childhood. This phenomenon of avoidance is interesting by its similitude with what Colin Turnbull remarked among the Mbuti, briefly described as a type of personal "allergies" (Turnbull 1965). 


\section{Avoidance, disgust, and animal symbolism}

see also Sperber 1975). For example, animals having a bad or strong smell tend to disgust people who consider such traits to be an anomaly. For this reason, mongooses, yellowbacked duikers, genets, otters, and buffaloes are not really appreciated and are often avoided, in that sense they are considered as having a strong kilà, a potential harmful effect on humans. As among the Aka (Thomas et al. 1981-2014), the materialist justification of this avoidance (i.e., the bad smell) originates in the idea that the animal smell might be a potential source of illness transmission through aerial contamination. Anomalies might also be morphological, behavioral, or spiritual, such as in the case of the aardvark, the otter or the crocodile (Figure 14), which are living, like spirits, live at the interface of two spaces (water and ground, or ground and underground). This is also the case for animals whose categorization is blurred (such as bats, and flying squirrel for instance $)^{11}$. As reported by Ichikawa (2007), the animals are before all mediators between humans and the spirit world. As apes do, they therefore carry in themselves this duality, whose "bad" aspects the Baka fear, will be ingested during their consumption.

\section{Domesticity}

Domestic animals are excluded from the category of animals "good to eat" because of their spatial proximity to humans. In a way, domestic animals are not wild enough to be eaten. This representation implies a concept of purity in which forests are opposed to villages, where human waste accumulates and might be a source of food for straying domestic animals. The pig ${ }^{12}$ is the animal most systematically refused for such symbolic and sanitary reasons (Figure 14), but other animal such as goats, sheep, and cows are also avoided. Although the Nzime and other non-Baka people largely accept the consumption of domestic animals, indeed domestic animals also contribute very little to the daily diet of these groups and are mainly reserved for social and festive events (e.g., the visit of a guest, a dowry payment, or meeting for mourning or weddings) (Bahuchet 2000). The chicken is the only domestic animal the Baka consume during festive events, often being given or received in the context of mourning or funerals to the family of the deceased. Hens are also part of Baka wealth, as they might be used for exchanges with non-Baka. However, hens are more consumed by young people, whereas elders continue to avoid the consumption of domestic animals ${ }^{13}$.Indeed, all across south-eastern Cameroon, before the generalization of money payment, local populations had to pay offenses against the customary laws by giving chicken (or sheep). This practice is still current, and we could identify during fieldwork several gifts of chickens as payment of the fines imposed by the traditional Nzime chefferie, by the eco-guards, or by the police, a practice adapted to the lack of cash among the Baka, and which reinforces the idea that hens is considered as a capital kept to face unexpected events, rather than a source of food. 


\section{Lineage names and "totemic" avoidance}

Among food avoidances, the totemic avoidance, a permanent avoidance, is the easiest to isolate. Among the Baka, everyone belongs to the father's lineage, called yée-, whose name makes reference to a non-human being. Lineage membership often implies a species' avoidance.

40 lineage names reported by Robert Brisson (2010) add to a total of 35 lineage names in south-eastern Cameroon ${ }^{14}$. Figure 15 presents the meaning of the lineage names in relation to their potential impact on food restrictions. Lineage names represent a wide diversity of life forms including 14lineage names correspond to animals (including 11 mammals) and eight to plants. Four lineage names also refer to valued cultural objects (i.e., knife, honey basket or drum),four to honey-gathering techniques, and four to others elements. Among the 14 lineage names corresponding to animals, two names correspond to specific categorization of a culturally important species but not the entire species: yéendonga (referring to solitary male gorilla) and yée-koambé (referring to solitary male elephant).

41 It appears that there is no consensus between the interviewees about strict avoidance of consuming the animal bearing the name of their lineage. Moreover, people also reported that there are always remedies to prevent potential harmful effects of the consumption of a species that should have been avoided. Overall, we did not find rituals nor specific practices or beliefs related to the lineage name. When looking at lineage names, and taking into consideration that edible few species mentions that are considered as edible by the Baka are in fact rarely used as lineage names are rarely consumed, the effect of lineage names over people's behavior towards the corresponding animals seems null. 
Figure 15: Patrilineage's names and potential effects on diet

\begin{tabular}{|c|c|c|c|c|}
\hline Lineage name & Meaning (Brisson, 2010; and own data) & Category & Impact on diet & Reason* \\
\hline Yé mboko & The african forest buffalo & Animal & Reduced & Rarely hunted \\
\hline Yé koambe & The male elephant that walks alone & Animal & No & Rarely hunted \\
\hline Yéwala & A mouse (undet.) & Animal & No & Rarely hunted \\
\hline Yé ndonga & The solitary male gorilla & Animal & No & Rarely hunted \\
\hline Yé mambe & The crested mona monkey & Animal & Yes & Hunted and consumed \\
\hline Yé likemba & A mushroom (dokpoli) (undet.) & Mushroom & No & Rare \\
\hline Yé mongbele & The pollen of the honey dandu & Honeygathering & No & Not consumed \\
\hline Yé yanji & The fire packet for somking bee hives & Honeygathering & No & Non-consumable \\
\hline Yé makombo & The african corkwook tree & Vegetal & No & Not consumed \\
\hline Yé mombito & The fruit of the plant maakpa (undet.) & Vegetal & No & Not consumed \\
\hline Yé ?esilo & Aliana & Vegetal & No & Not consumed \\
\hline Yé njembe & Aliana (similar to liana kusa) & Vegetal & No & Not consumed \\
\hline Yéndumu & The traditional Baka drum & Material culture & No & Non-consumable \\
\hline Yé ndongo & The other name of the drum ndumu & Material culture & No & Non-consumable \\
\hline Yé bombi & (Unidentified) & - & - & - \\
\hline Yé bosala & The other name of the big bat ngbee (undet.) & Animal & No & Not hunted \\
\hline Yé kema & The category referring to monkeys & Animal & Yes & Hunted and consumed \\
\hline Yénganda & the marsh mongoose & Animal & Yes & Hunted and consumed \\
\hline Yémbongo & The Bongo & Animal & Yes & Hunted and consumed \\
\hline Yé polo & the Demidoff's galago & Animal & Occasional & Not hunted \\
\hline Yé sua & The panther & Animal & No & Not hunted, not consumed \\
\hline Yé mbùmà & The Gabon Viper & Animal & Yes & Hunted and consumed \\
\hline Yé mokumù & The other name of the snake ngeke (undet.) & Animal & ND & ND \\
\hline Yé mopanje & An insect (undet.) & Animal & No & Non-consumable \\
\hline Yé yoli & The mytical snake, father of all snakes & Animal (mythic) & No & Non-consumable \\
\hline Yé pendi & The honey basket & Honey gathering & No & Non-consumable \\
\hline Yé tongyà & The african bee & Honey gathering & No (indirect) & Non-consumable \\
\hline Yéguga & The stool tree & Vegetal & ND & ND \\
\hline Yé kusa & Manniophyton liana & Vegetal & No & Not consumed \\
\hline Yé tondo & The fruit of nijyi (Grape-seeded amomum) & Vegetal & Yes & Not consumed \\
\hline Yé wondo/mbunù & The groundnut & Vegetal & Yes & Consumed \\
\hline Yé ?esolo & The natural spring & Environment & No & Not hunted \\
\hline Yélàmbà & The knife's edge & Material culture & No & Non-consumable \\
\hline Yé ngila & The stick used to beat people & Material culture & No & Non-consumable \\
\hline Yé kpotolo & The one "who fear the ground" & Other & No & - \\
\hline
\end{tabular}

\section{Evaluation of bushmeat consumption}

Along with its social and cultural importance, meat also holds nutritional and economic importance for the Baka. After obtaining some meat, both household heads (man and woman) evaluate and decide its fate according to the household's needs: keep the harvest for consumption, distributed as gift, or sold it (Bahuchet \& Ioveva 1999, Bahuchet 2000). The number of animals obtained and their size usually condition how meat is divided among these three possibilities. We focus here firstly on wild meat for household consumption and then on wild meat for sale.

\section{Seasonality in meat consumption}

According to the results of our dietary recalls, adults consumed meat on $25 \%$ of the reported days. The major dry season (from December to mid-March) is the period when meat consumption peaks (meat reported in $31 \%$ of the diet observations), while the major rainy season (from September to November) and the minor dry season (from July to August) are the periods with least meat in the diet (21\% in both cases). It is worth highlighting here that because less data were collected during the minor dry season, meat consumption might have been misestimated compared to the other seasons.

Wild meat reported in dietary survey was sometimes bought locally. The share proportion of meat bought varies slightly depending in the season (from $2.63 \%$ of the total during the short dry season to $6.73 \%$ during the long dry season). The share of meat coming from the market is generally proportional to the global meat consumption ( Figure 13). 


\section{Gendered variations in meat and fish consumption} meat more often than women ( $28 \%$ of the reported days for men and $22 \%$ for women). However, these numbers vary differently across age categories. Adolescent and young men reported meat consumption more often than adolescent and young women $(<35$ years of age). Between 35 and 54 years of age, the trend is inverted, and men tend to have a less meat than women in their diet. Moreover, children tend to get a higher dietary diversity than adults, especially due to their more frequent consumption of meat (see Reyes et al. 2018). It should be noticed that, while these results are interesting in terms of the general tendency, they do not allow us to discuss the amount of meat actually consumed.

Figure 16: Percentage of observations in which consumption of meat was reported, by age and sex

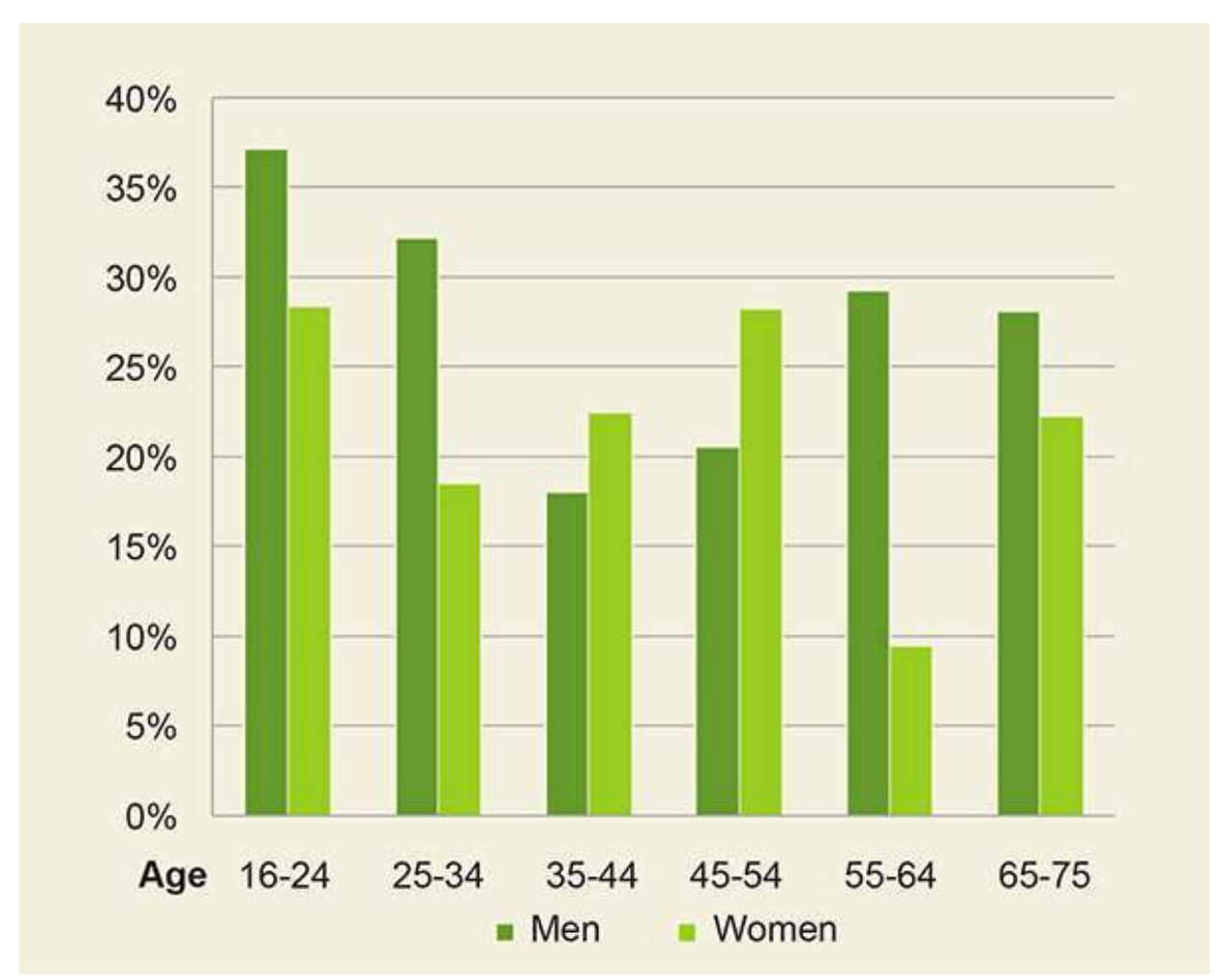

Comparing men's and women's meat with fish and shellfish consumption (Figure 17), we find that, overall, meat is consumed more frequently than fish. Women reported having eaten fish in $12 \%$ of the self-reported recalls, and men in $10 \%$, with men between 45 and 64 years of age consuming less fish than all the other categories, and elders reporting have eaten fish most often. 
Figure 17: Percentage of fish and shellfish in the self-reported recalls (1 day) according to age and sex

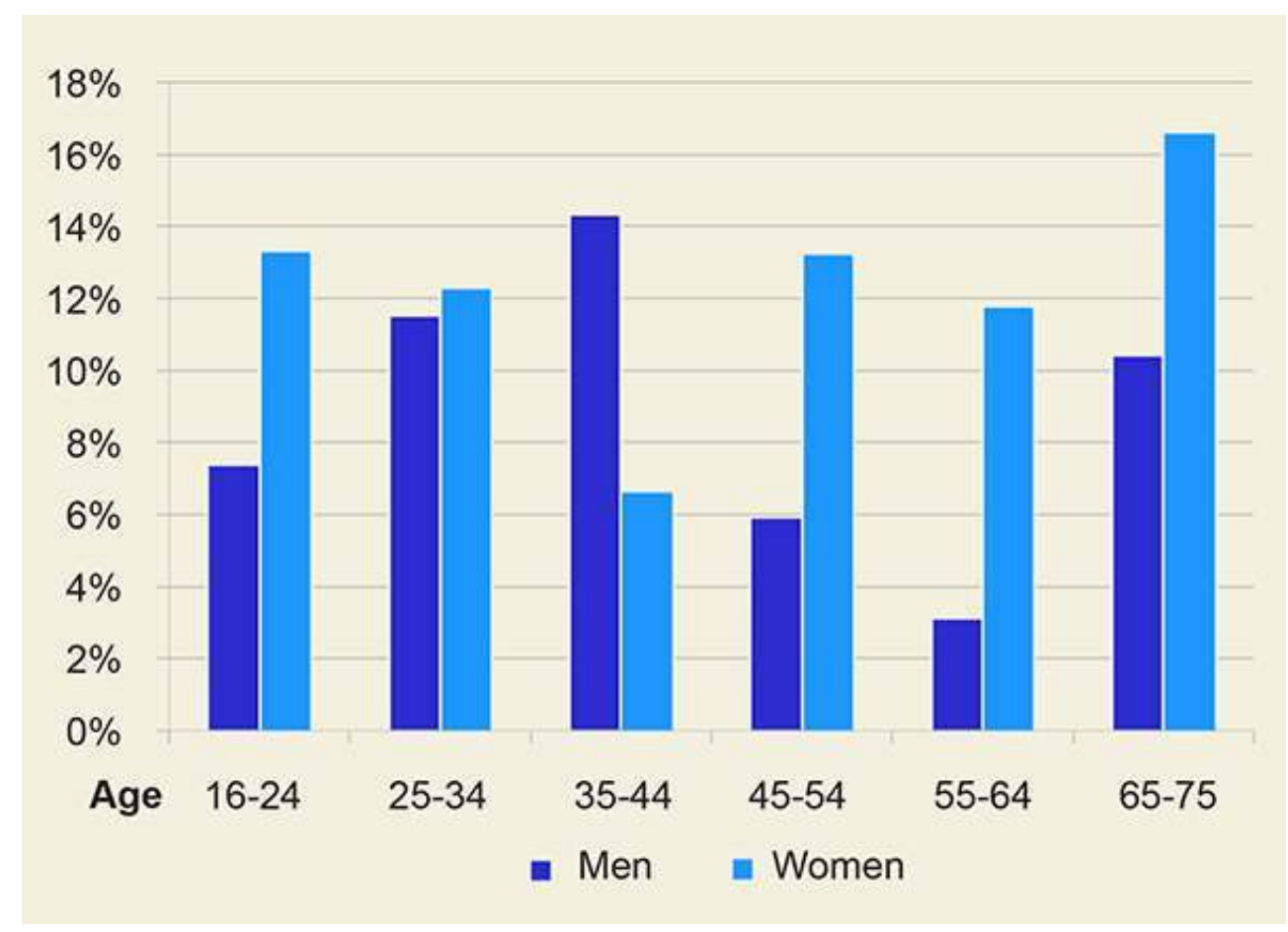

\section{Species consumed}

The analysis of meat consumption by adults suggests that the Baka consume a high diversity of species (Figure 18 and examples illustrated by figures 19 to 24). Specifically, they reported consuming 19 species $^{15}$, ranging from mice to the elephant. However, there is great variation in the number of times each species appears (Figure 19). The most reported species is the Emin's pouched rat, reported in almost 30\% of the observations), followed by the blue duiker (16\%). $90.6 \%$ of the reported observations of animal consumption are accounted for by three groups: rodents (rats, porcupines, and mice: $48.4 \%$ ), ungulates (35.2\%), and monkeys (7\%), These three groups are known to be most frequently consumed by populations of the Congo basin in general (Bennett \& Robinson 2000, Fa \& Brown 2009, Nasi et al. 2011). Species belonging to other groups are diverse but more rarely consumed, all being reported only one to five times over the studied period.

The two most surprising results regarding bushmeat consumption among the Baka are the important proportion in adult diets of rodents consumed, particularly the Emin's pouched rat, and the unexpected high frequency of consumption of mice among adults, although this is considered by the Baka to be a "children's meat" (Gallois 2015).

We found that the Emin's pouched rat is consumed very frequently, something that has not been previously reported in the literature. Indeed, a comparison of data across the two villages shows that EL village accounts for $76 \%$ of the total observations of consumption of Emin's pouched rat. This variation might be explained by differences in geographical location ofthe two villages. EL village is closer to the regional market town (Lomié) and shows a hunting harvest structure typical of highly degraded environments (high offtake of small-sized mammals, notably rodents). It is reasonable to interpret the importance of rodents in diet of inhabitants of EL village as the result of higher hunting 
pressure in the past years. People in MB village consume a large proportion of small mammals whose high reproductive rates (porcupine, blue duiker, rat) confer resilience in the face of hunting. However, their hunters have the possibility to hunt in more remote areas (road access to these areas, more logging trucks passing allowing faster displacements) and can hunt more often with shotgun due to a higher proximity of the Nzime village compared to EL village.

Figure 18: Frequency of consumption of animal species and hunting rates

\begin{tabular}{|l|c|c|c|}
\hline English name of the species & Baka name & Consumption frequency & Hunting rates \\
\hline Emin's-pouched rat & gbe & 86 & $27.81 \%$ \\
\hline Blue duiker & dengbe & 47 & $27.63 \%$ \\
\hline Peter'sduiker & ngendi & 36 & $4.84 \%$ \\
\hline Brush-tailedporcupine & mboke & 30 & $8.64 \%$ \\
\hline Mice & bili & 23 & $6.91 \%$ \\
\hline Monkeys & kema & 19 & $11.92 \%$ \\
\hline Bayduiker & ngbomu & 11 & $1.55 \%$ \\
\hline Treehyrax & yoka & 5 & $0.35 \%$ \\
\hline Marsh mongoose & nganda & 5 & $1.21 \%$ \\
\hline Sitatunga & mbuli & 5 & $0.00 \%$ \\
\hline African palm civet & mboka & 3 & $1.38 \%$ \\
\hline Africanforestelephant & ya & 3 & $0.00 \%$ \\
\hline Common tortoise & kunda & 3 & $0.86 \%$ \\
\hline Snail & bambe & 2 & $0.00 \%$ \\
\hline Tree pangolin & kokolo & 2 & $2.76 \%$ \\
\hline Yellow-backed duiker & bemba & 2 & $0.52 \%$ \\
\hline African civet & liabo & 2 & $0.00 \%$ \\
\hline Chicken & koko & 1 & 1 \\
\hline Gabon viper & mbuma & 1 & 0 \\
\hline Lowlandgorilla & ebobo & 1 & $0.35 \%$ \\
\hline
\end{tabular}

Figure 19: Share of species consumed by adults (except meat bought)

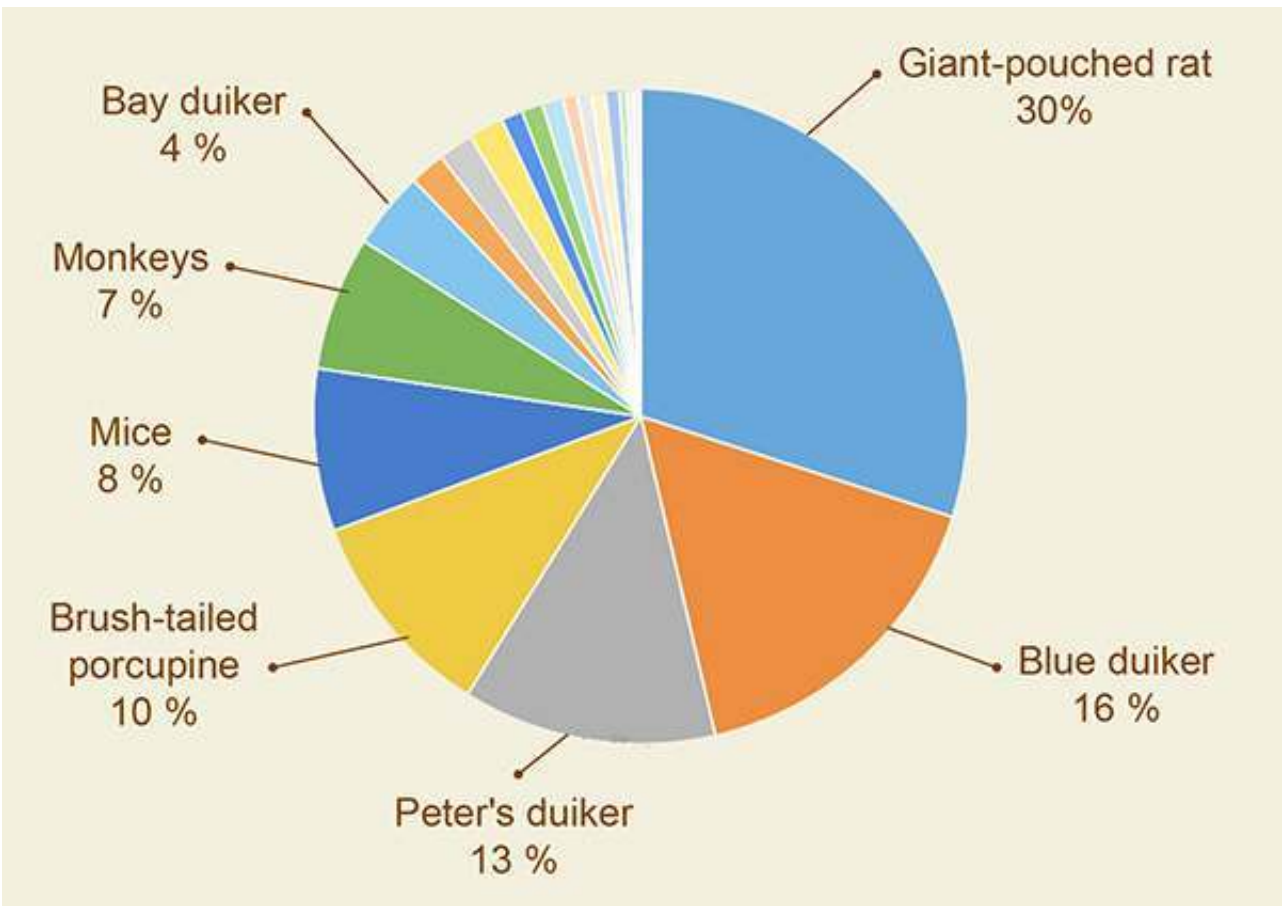


Figure 20: Brush-tailed porcupine cooked in a forest camp

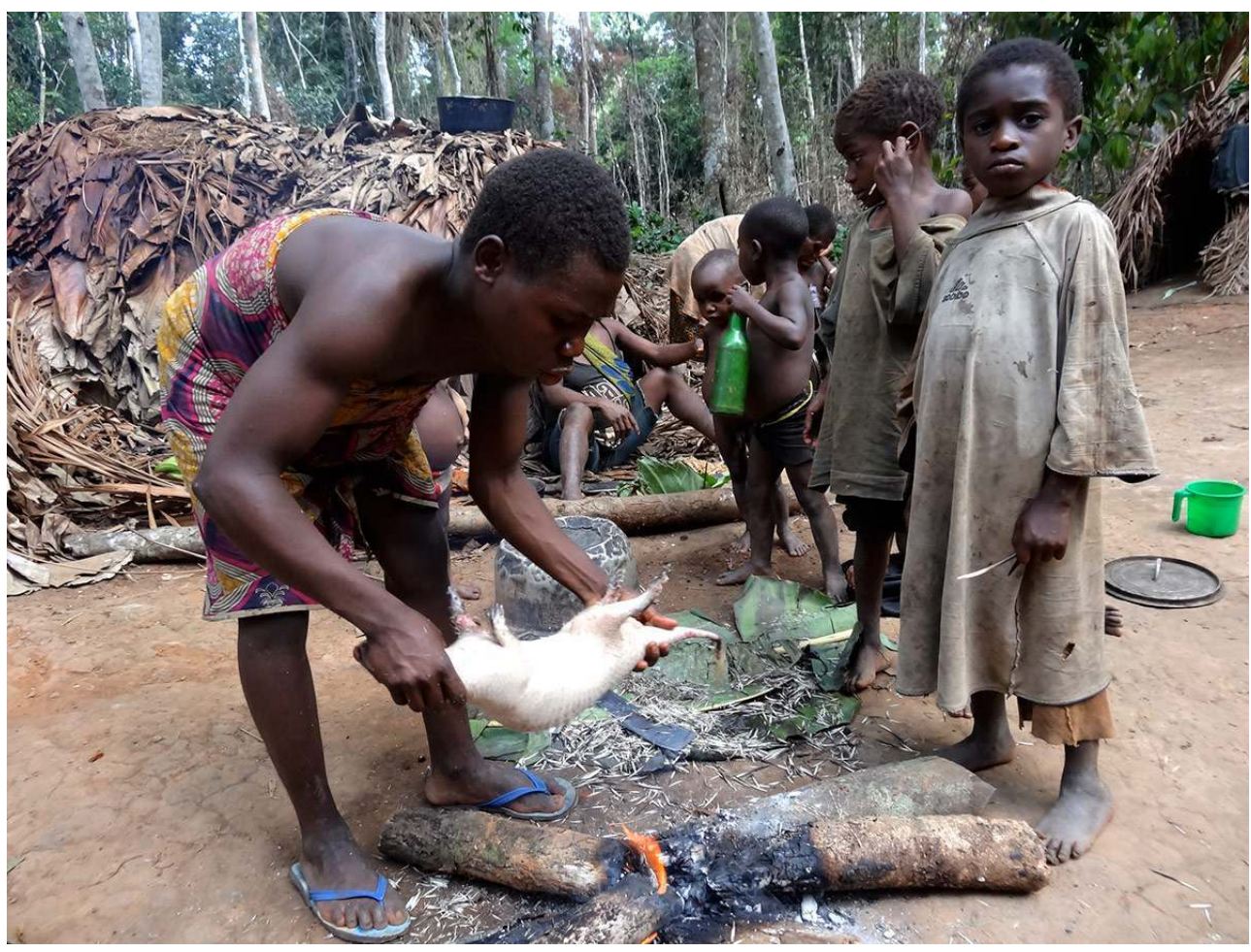

(c) R. Duda

Figure 21: Immature Red river hog (Potamochoerus porcus) and brush-tailed porcupine (Atherurus africana)

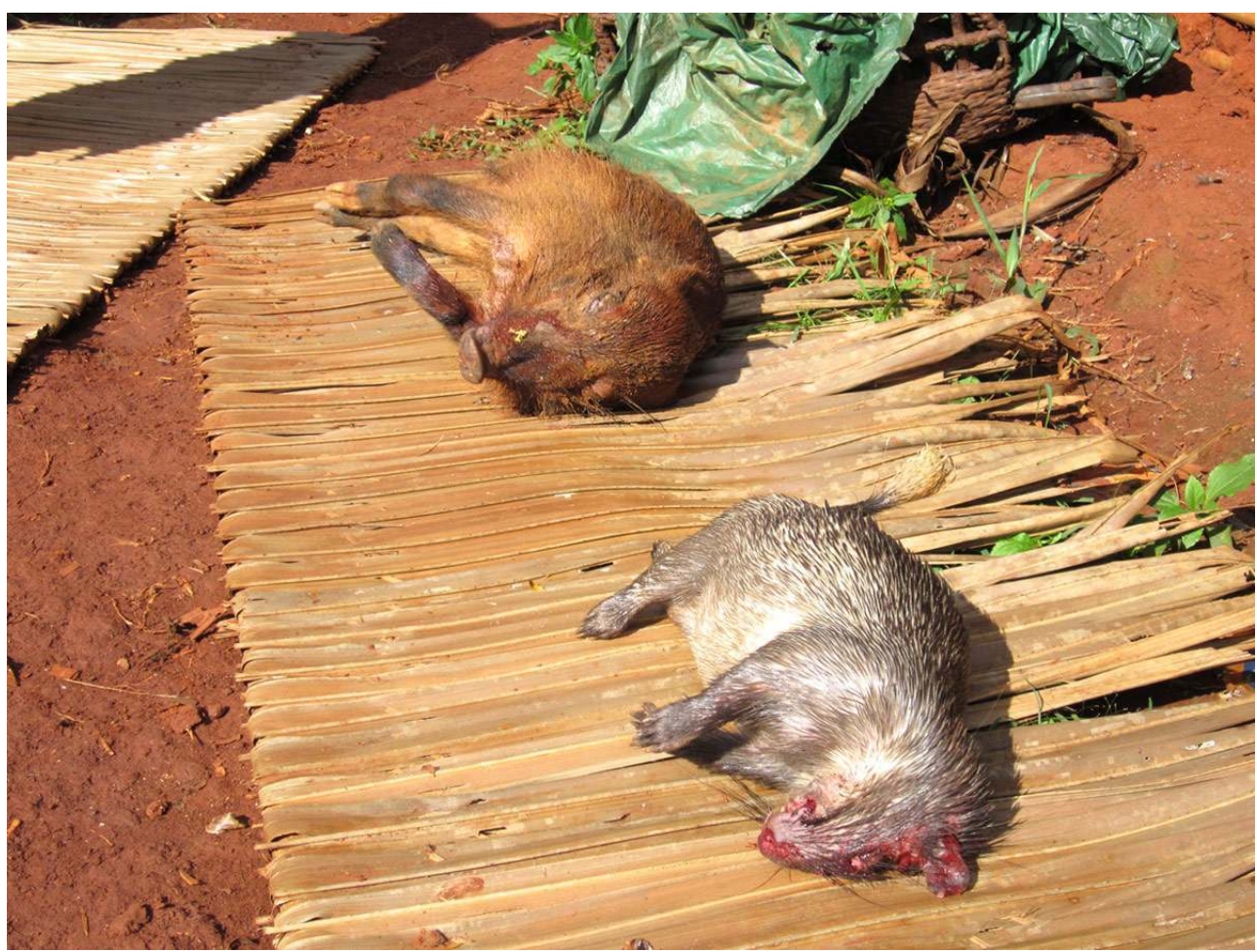

(C) R. DUDA 
Figure 22: African palm civet (Nandinia binotata)

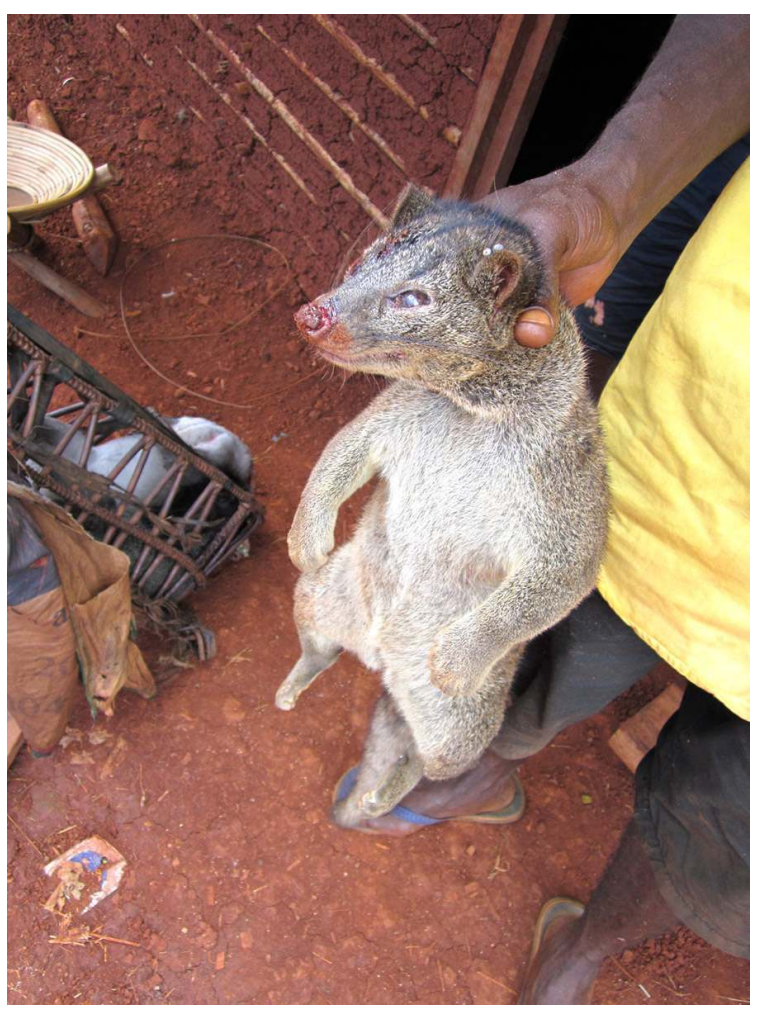

(c) R. Duda

Figure 23: Tree pangolin (Phataginus tricuspis)

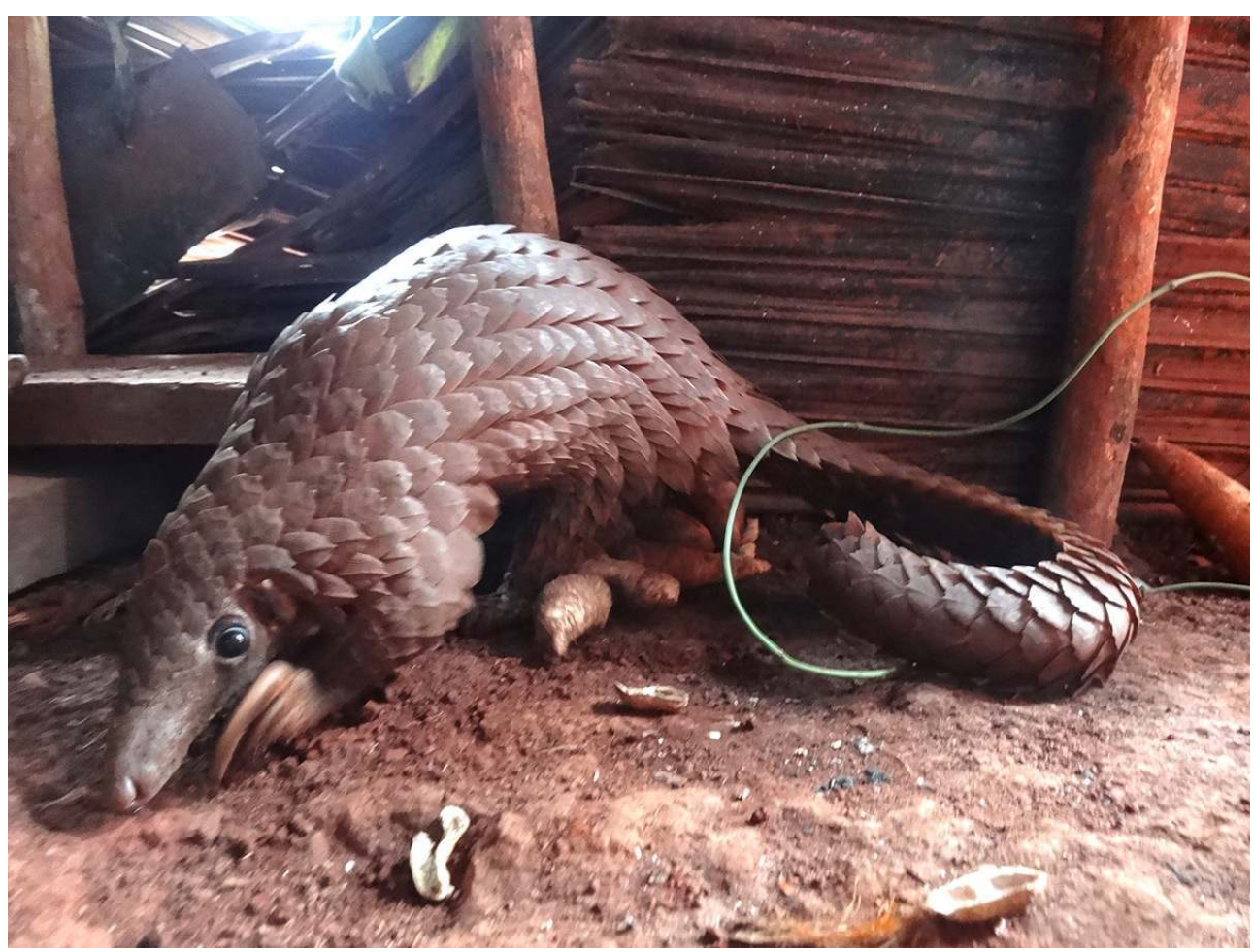

(c) R. Duda 
Figure 24: White-tighted hornbill (Bycanistes albotibialis) killed with a shotgun

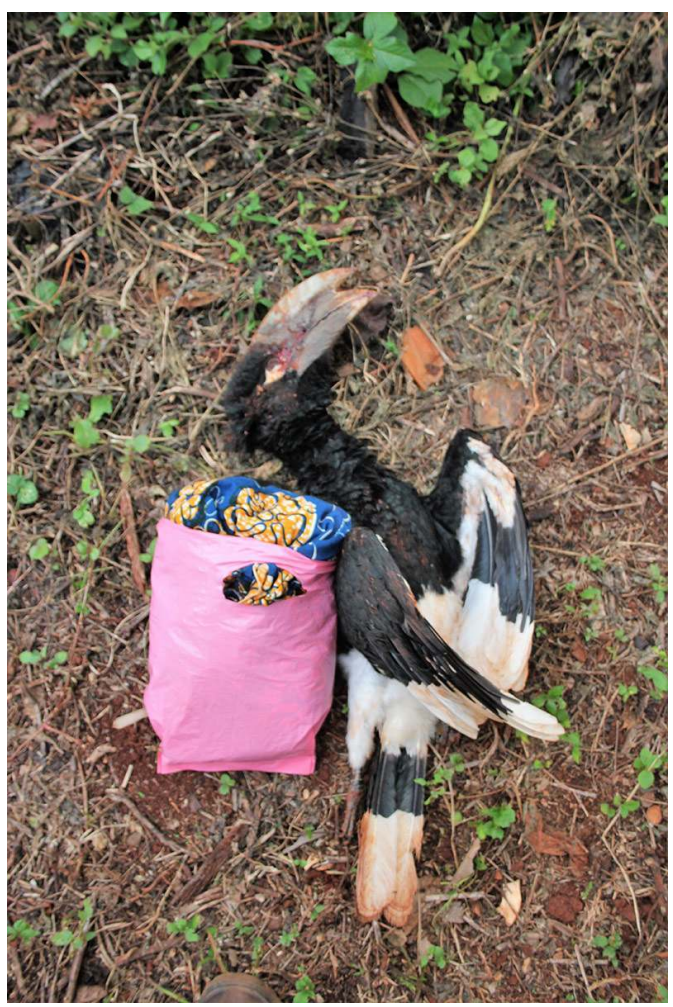

(c) R. Duda

Figure 25: Mouse trapped by children with a vegetal snare trap

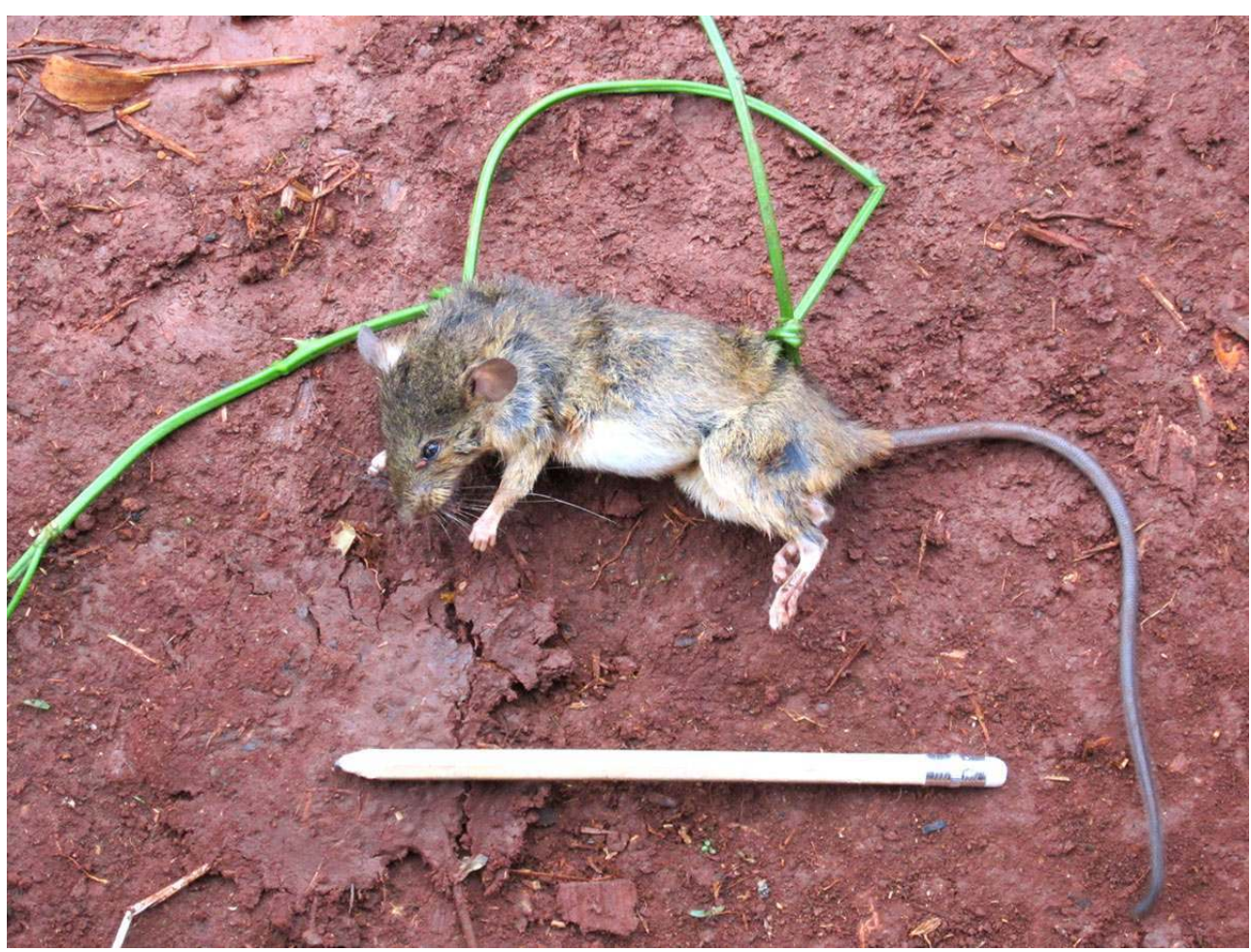

(c) R. Duda 


\section{Taste preferences}

50 duiker appear as the most preferred game to eat (Figure 25). In parallel, three species were listed as appreciated as food but being almost never hunted in the studied villages: the red river hog, the giant pangolin, and the elephant. Informants reported that they appreciated these three species because of the amount of fat in their bodies, notably the red river hog and the elephant. It should be noticed that, although elephant's meat is not considered to be the best tasting, elephant is recognized by the Baka as the game par excellence, because, among other reasons, it relates with food abundance allowing sharing among many other community members, both strong aspects of the "well eating" among the Baka (Joiris 1996). Moreover, most informants mentioned that they no longer have the opportunity to eat this meat. Indeed, when probed about their favorite meat, people seem to think first of species whose meat is commonly available. This tendency has already been reported by Kümpel et al. (2007), who found that bushmeat preferences are largely related to availability

Interestingly, some of the most appreciated species, such as the common pangolin, the giant pangolin, the red river hog, or the elephant, are almost never consumed, but that is supposedly explained by the rapid decline of these species in the area in the last decades due to overhunting. The older interviewees reported to have eaten such species much more often in the past than today.

Figure 25: Ranking of animal species the Baka prefer to eat reported by a sample of 20 Baka in a free-listing exercise (average length of the list: 5 ; number of items elicited: 19)

\begin{tabular}{|c|c|c|c|c|c|c|}
\hline $\begin{array}{c}\text { Rank of preferred } \\
\text { species }\end{array}$ & English name & $\begin{array}{c}\text { Baka } \\
\text { name }\end{array}$ & $\begin{array}{c}\text { Number of report in } \\
\text { preferences lists }\end{array}$ & $\begin{array}{c}\text { Smith index of } \\
\text { preferences lists }\end{array}$ & $\begin{array}{c}\text { \% of catches in hunting } \\
\text { survey (12 months) }\end{array}$ & $\begin{array}{c}\text { Class in national } \\
\text { hunting regulation }\end{array}$ \\
\hline 1 & $\begin{array}{c}\text { Brush-tailed } \\
\text { porcupine }\end{array}$ & mboke & 17 & 0,62 & 8,64 & C \\
\hline 2 & Tree pangolin & kokolo & 11 & 0,394 & 2,76 & C \\
\hline 3 & Red river hog & pame & 11 & 0,372 & 0,52 & B \\
\hline 4 & Blue duiker & dengbe & 9 & 0,311 & 27,63 & C \\
\hline 5 & Peter's duiker & ngendi & 8 & 0,278 & 4,84 & B \\
\hline 6 & Giant pangolin & kelepa & 8 & 0,19 & 0 & A \\
\hline 7 & Forest elephant & ya & 6 & 0,164 & 0 & A \\
\hline 8 & Bay duiker & ngbomu & 5 & 0,135 & 1,55 & B \\
\hline 9 & Lowland gorilla & ebobo & 4 & 0,089 & 0,35 & A \\
\hline 10 & (all monkeys) & kema & 3 & 0,043 & 11,92 & 0 \\
\hline 11 & African buffalo & mboko & 2 & 0,058 & 0,17 & A \\
\hline 12 & Water chevrotain & akolo & 2 & 0,034 & & A \\
\hline
\end{tabular}

Figure 26:

\section{Eating meat or getting cash? The influence of bushmeat trade of the fate of meat}

This section explores bushmeat commercialization. We first look at the cash obtained from selling meat and the importance of different species in this trade, and then provide in-depth explanation of the functioning of the bushmeat economy and the various social and economic incentives that influence both hunting and economic decisions. 


\section{Prevalence of bushmeat in the Baka monetary economy}

monetary value of products sold by the Baka comes from the sale of wild products, and bushmeat contributes to half of this value. The Baka reportedly sold 12 different game species $^{16}$. Other important sources of income are plant products, mainly seeds of Pentaclethra macrophylla and leaves of Gnetum africanum. Elephant tusks and pangolin scales, two products sold for export, represent $5 \%$ of the income ${ }^{17}$. The sale of "other wild products", such as honey and mushrooms, and of agricultural products does not contribute much to total income. The sale of domestic animals includes only trivial contributions from sales of puppies and hens.

Figure 28 presents the contribution, in monetary value, of the different species sold over the study period ${ }^{18}$. Duikers represent the species with a highest percentage to the total income from bushmeat sales (67\%). The Blue duiker, the most hunted duiker species, is the species that provides the largest monetary income for the Baka, followed by the bai duiker, Peter's duiker, and brush-tailed porcupine. Monkeys, grouped together, contribute to $7 \%$ of cash income from the sale of bushmeat. Chimpanzee, although very rarely hunted, accounted for $5 \%$ of the monetary value of bushmeat sales, owing to its high market value. However, several informants reported that when a protected species is killed, people preferably consume it directly because of the difficulty and the risk of selling protected species on the market (notably gorilla, giant pangolin, chimpanzee, and obviously elephant). 
Figure 27: Contribution of bushmeat to income from sales, compared to others products

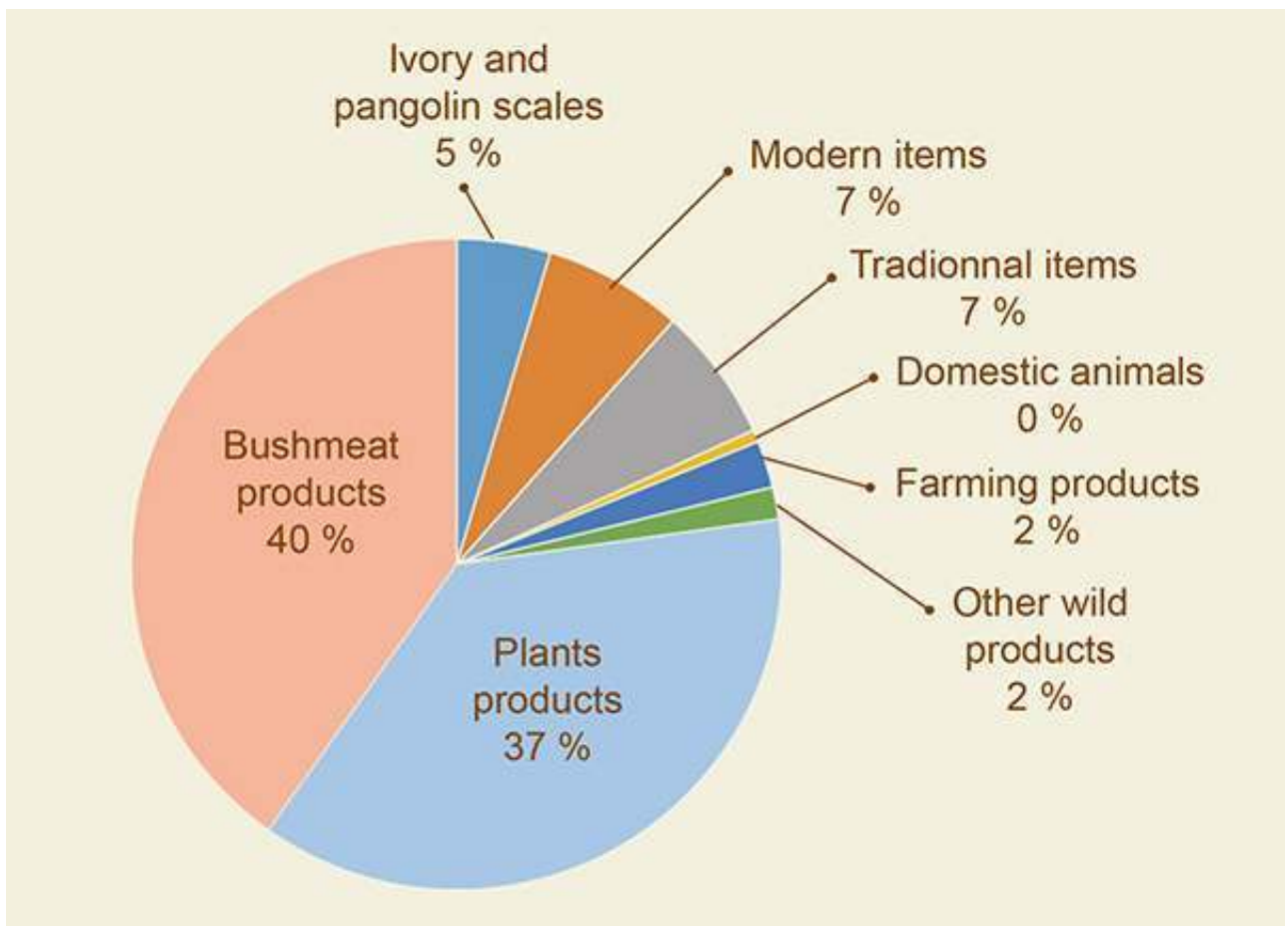

Figure 28: Share of income from bushmeat selling, by species

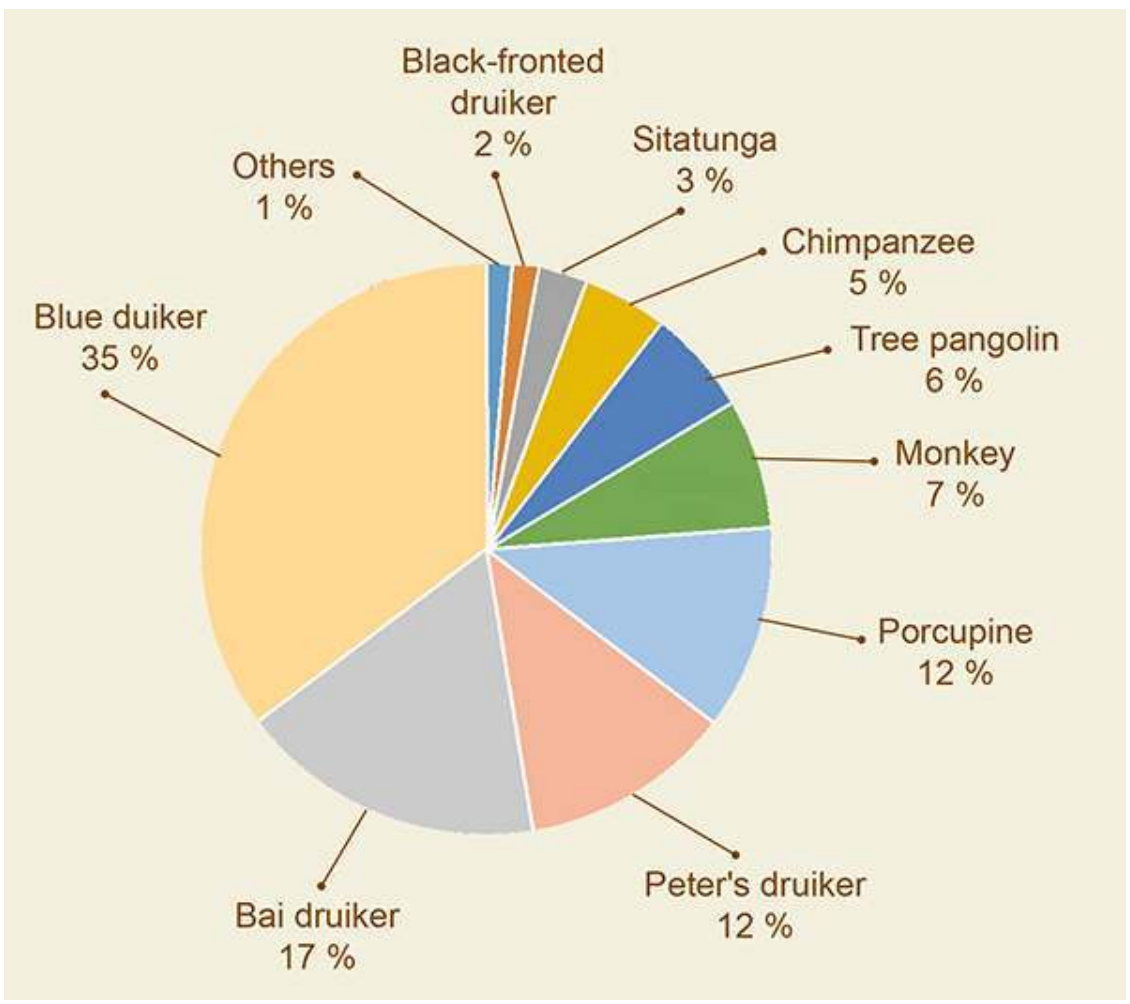




\section{Motivations for hunting: subsistence and economic needs}

A hunting trip is often decided from one day to the next, depending on immediate needs and possibilities. Figure 29 summarizes the potential decisions a hunter and his household might take prior to the hunting expedition depending on the motivation, i.e. hunting to procure either 1) meat or 2) money. Typically, the weapon and the way the meat is procured both systematically differ according to the motivation. This is specifically the case for shotgun hunters, who - according to the numbers of cartridges brought - have an idea of the number of game they might potentially kill.

Figure 29: Hunting decisions from the Baka perspective depending on motivations

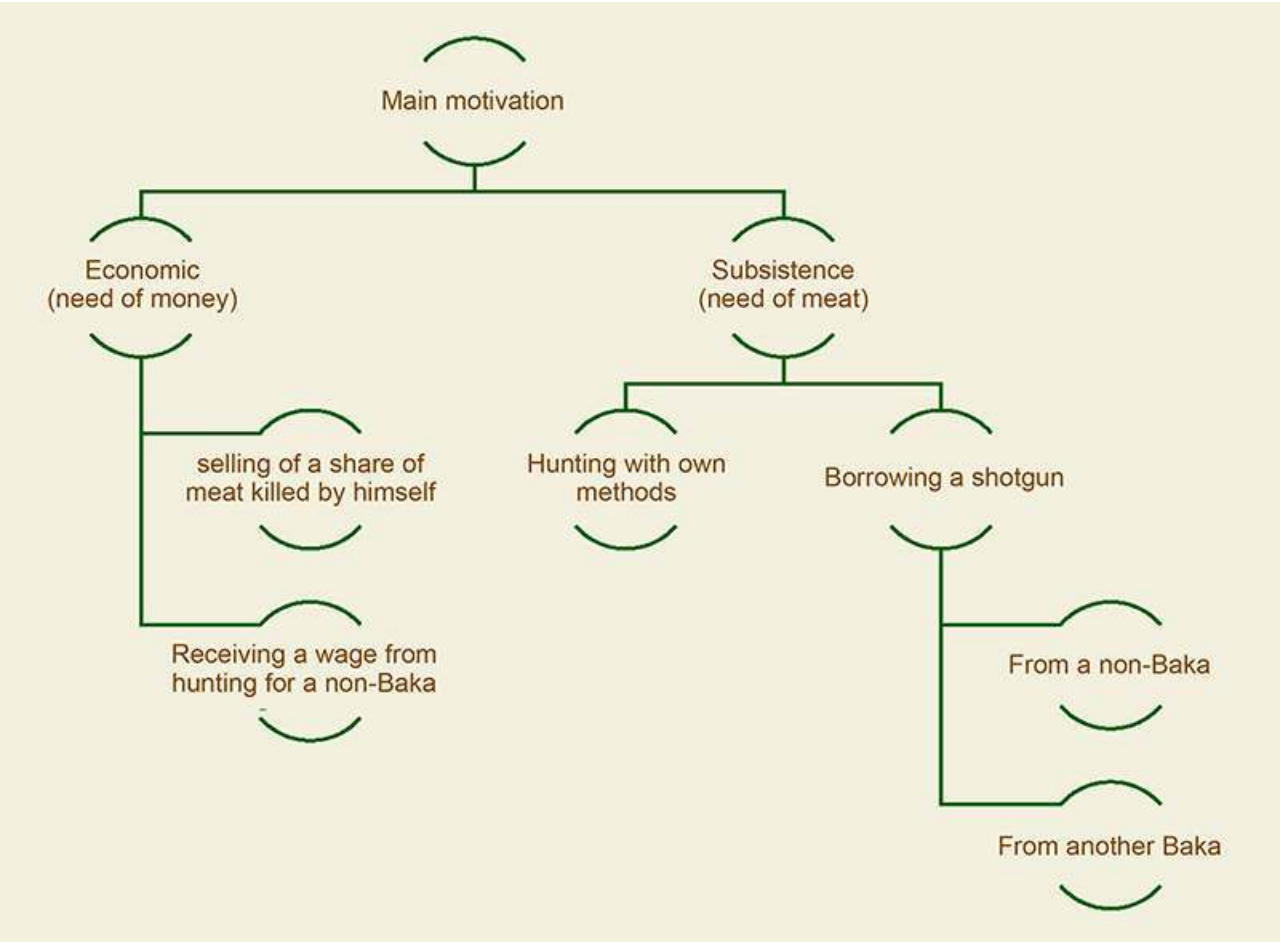

When hunting for subsistence, the hunter can visit snare traps, use his own weapons (spear, and more rarely shotgun) or borrow a gun either from a Baka co-resident or from an Nzime ally. The decision, however, is not always individual, and might be affected by social pressure and demand, notably by women who push the adult males to fulfil their role of "meat providers". When hunting to acquire money to satisfy occasional expenditures (e.g., school fees, funeral, cooking items, debt payment), hunters typically hunt for someone, usually an Nzime or a merchant gun owner, who will provide the hunter with a shotgun and cartridges in exchange of a wage (at the time of the survey, usually $1.000 \mathrm{Cfa}-1.5 €-$ for a day or a night). In some cases, the hunters might keep in counterparts the parts of the animal which are the less appreciated by the Nzime (i.e., the head, the skin, the internal organs, or the entrails) (Figure 30). 


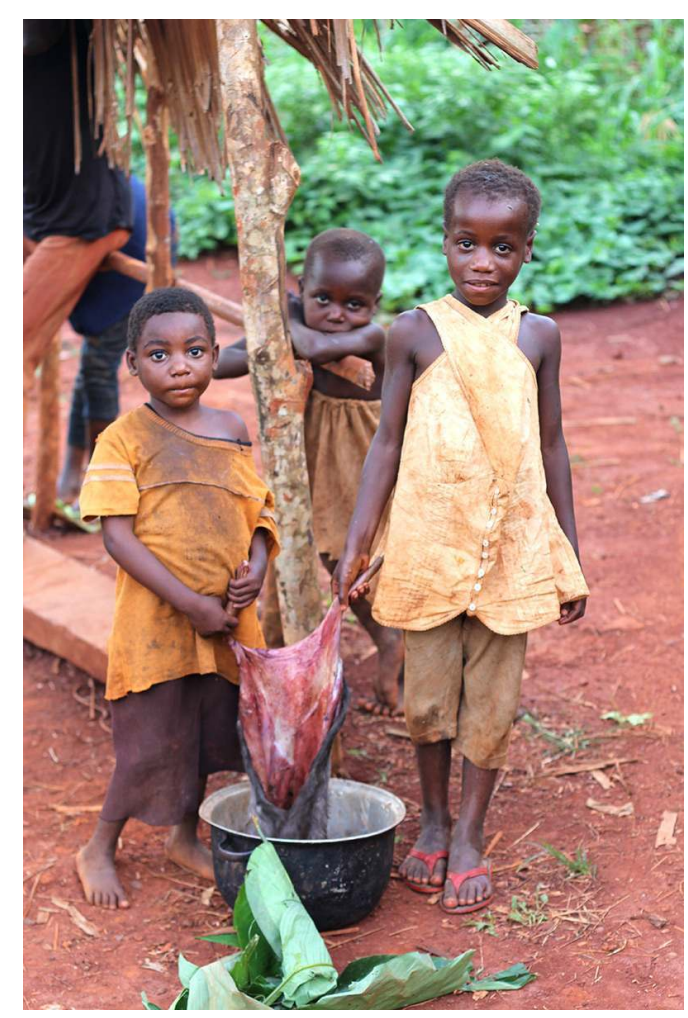

(c) R. Duda

The situation might be different for a hunter who goes to visit snare traps, as in such cases unsuccessful visits are frequent and hunters are most likely to decide the fate of the game once they have returned to the village and depending on the size or the number of animals brought. Informants also mentioned that the real possibility of actually selling the meat in the village as an important factor in deciding the fate of the meat. Overall, selling meat was easier in MB than in EL, given the proximity of the Nzime village and the larger number of merchants Figure 31). Indeed, the high value of bushmeat was an important incentive to many non-Baka people to make rapid deals by buying meat at a cheap price from the Baka and selling it at a higher price further away on the road. As the Baka often say: "meat always finds buyers".

However, the scarcity of wild meat will always push the hunter to keep first and foremost a share of the game for him and his family. After a hunt, or returning from visiting snares, the meat can be eaten in a forest camp to avoid jealousy. However, faced with occasional needs for money and pushed by the high value of meat, most Baka divide their harvest between household consumption and sale. Thus, depending on the quantity of meat harvested, the raw meat can either be entirely sold, or divided. If one animal is at the first stage of decomposition, this would be the one that will be smoked (to disguise the rotten aspect) and sold to traders or neighbours. Generally, when the size of the animal allows it, the most common system is to split the animal into halves, one half for household consumption and the other for sale. Finally, raw meat might also be divided into small parts and cooked in order to be sold as ready-to-eat pieces (i.e., jejep, see below). Figure 32 provides a general summary of the fate of different types of game 
brought to the household ${ }^{19}$, how are they generally divided, and what the household generally buys with money received if a part of the harvest is sold.

Figure 31: A village trader (Nzime) who bought bushmeat to a Baka hunter in order to transport and sell it the same day at the Messok market, where the meat can then continue to Abong-Mbang or Yaounde

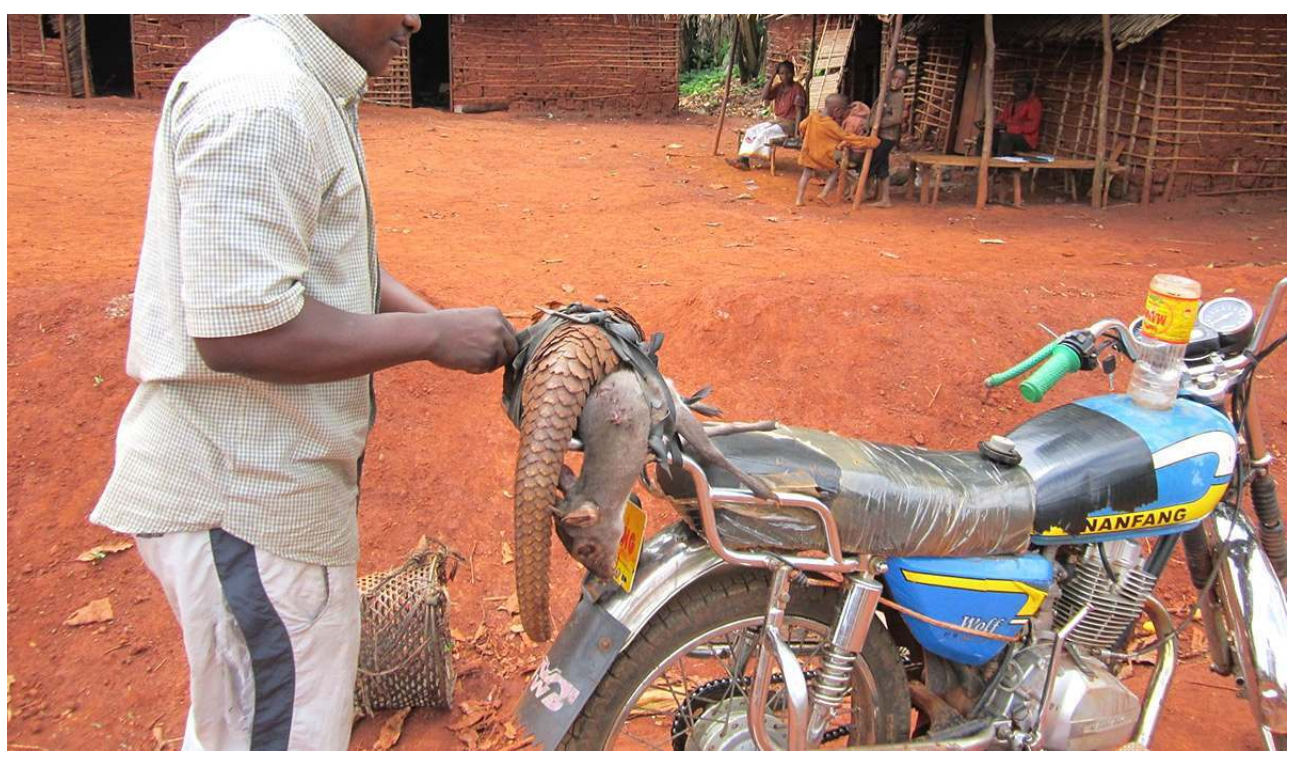

(c) R. Duda

Figure 32: Economic choices generally made by Baka households after game harvest

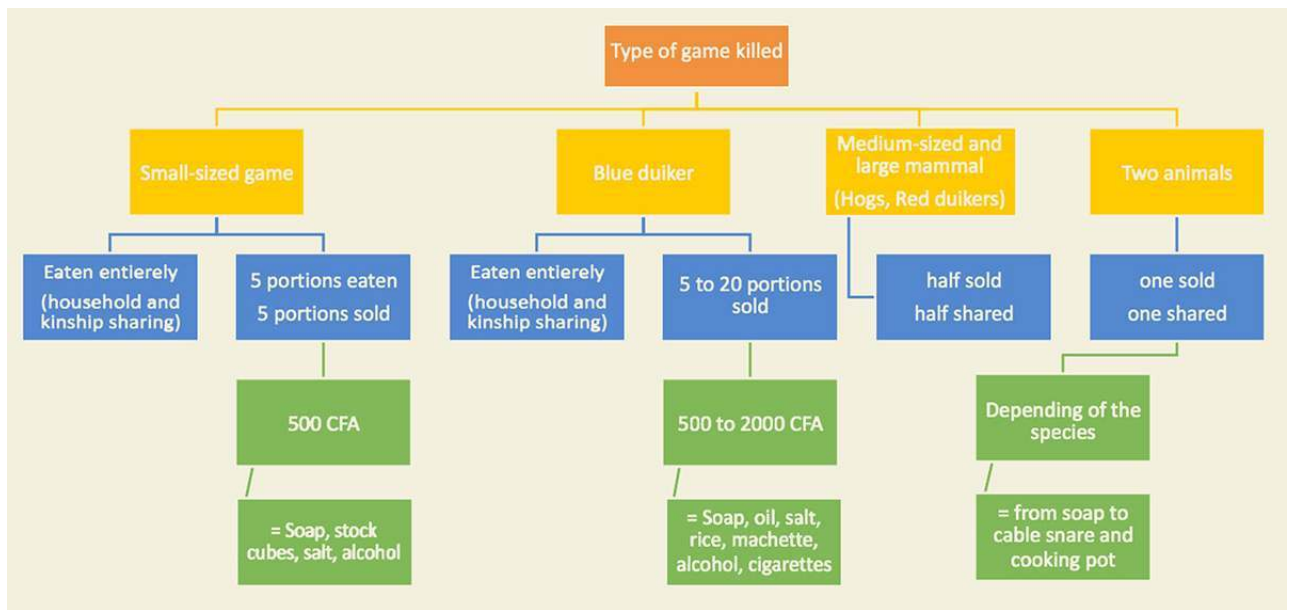

The "jejep": An opportunistic market for meat

Of all the observations of meat consumed, $17 \%$ correspond to small portions bought in the village by themselves. This meat consists of already cooked (boiled) portions of meat locally sold at affordable prices. This form of meat consumption is known as jejep, a name that comes from the fact that the presence of meat for sale is announced by adolescents or children who walk on the roads with a pot on the head shouting “jejep! jejep!". Mainly practiced by the Nzime (where meat is more likely to be bought and sold between themselves), the Baka are increasingly adopting it as a way to compensate the increasing difficulty of obtaining meat from hunting or sharing. Its popularity comes from the fact 
that it allows the household to keep a variable portion of the harvest (depending of the number of individuals in the household or relatives-receivers) and sell the rest. The size of portion is largely established. Thus, for instance a blue duiker gives $40 / 45$ shares, and a monkey 30 portions. Moreover, this type of trade is not considered as illegal regarding the law (familial consumption or inner-village trade is defined as "chasse vivrière").

Although the possibility of buying meat is reduced for the Baka, who generally have low levels of cash income, people are selling jejep targeting both the Nzime and the Baka. Given its low price, 100 francs CFA ( 0.15 euros) the portion, most Baka can afford to buy one or two pieces of meat in case of meat-hunger, to nourish children, or as a gift for guests or family-in-law.

The fact that some Baka are buying meat is interesting as it shows the extent to which meat-hunger, related to the wildlife decline in the area, might push the Baka to punctually buy meat on the market. The acquisition of bushmeat by the Baka highlights a relative imbalance between subsistence and market economy, as well as a relative decline of extensive meat-sharing norms and a demand-sharing system that previously allowed counteracting of the temporal lack of meat undergone by some households. The phenomenon might also lead to the paradoxical situation when a Baka hunter might buy a cooked piece of an animal he has hunted himself for an Nzime (in exchange for money), and which the Nzime decide to sell through jejep in the Baka villages.

\section{Meat sales in a context of jealousy and anti-poaching}

Besides jejep selling, the way in which the Baka sell meat reveals the social relations within the society and with neighbors. When game is brought to the village, a child is often sent to the Nzime village (notably to the house of the hunter's Nzime partner house) to communicate that meat is on sale (when the game is big enough. Contrarily to their neighbors, the Baka never hang the game in front of their house to signal the sale (Figure 33), as they fear repression from ecoguards and, most of all, the jealousy of other village members who might criticize the hunter for selling rather than sharing the meat (Leclerc 2006). As the Baka hunt more than their neighbours, Nzime merchants and other Cameroonian traders chose to settle within the Baka settlements, making meat trade with them their principal or secondary trading activity. From there, they can initiate close relationships with hunters and buy meat or organize hunts directly with them, beneficiating a monopolitis position.

Hunters who regularly bring large amounts of meat might also be directly approached by Nzime and merchants who ask if wild meat is available or when it will be. These opportunistic sales represent, in fact, most of the Baka meat trade, who recognizes that selling meat is now much easier and more profitable than in the recent past.

"Today it's hard to kill, but on the other hand there are more buyers than before because meat is rare. There are sometimes several buyers for a piece". [I.B., male, 41 years old, EL village] 
Figure 33: Along the dirt roads, in front of the Nzime houses (but never in front of Baka houses), smoked bushmeat is often exhibited for sale, allowing notably to logging trucks drivers to quickly visualize the product and stop if interested

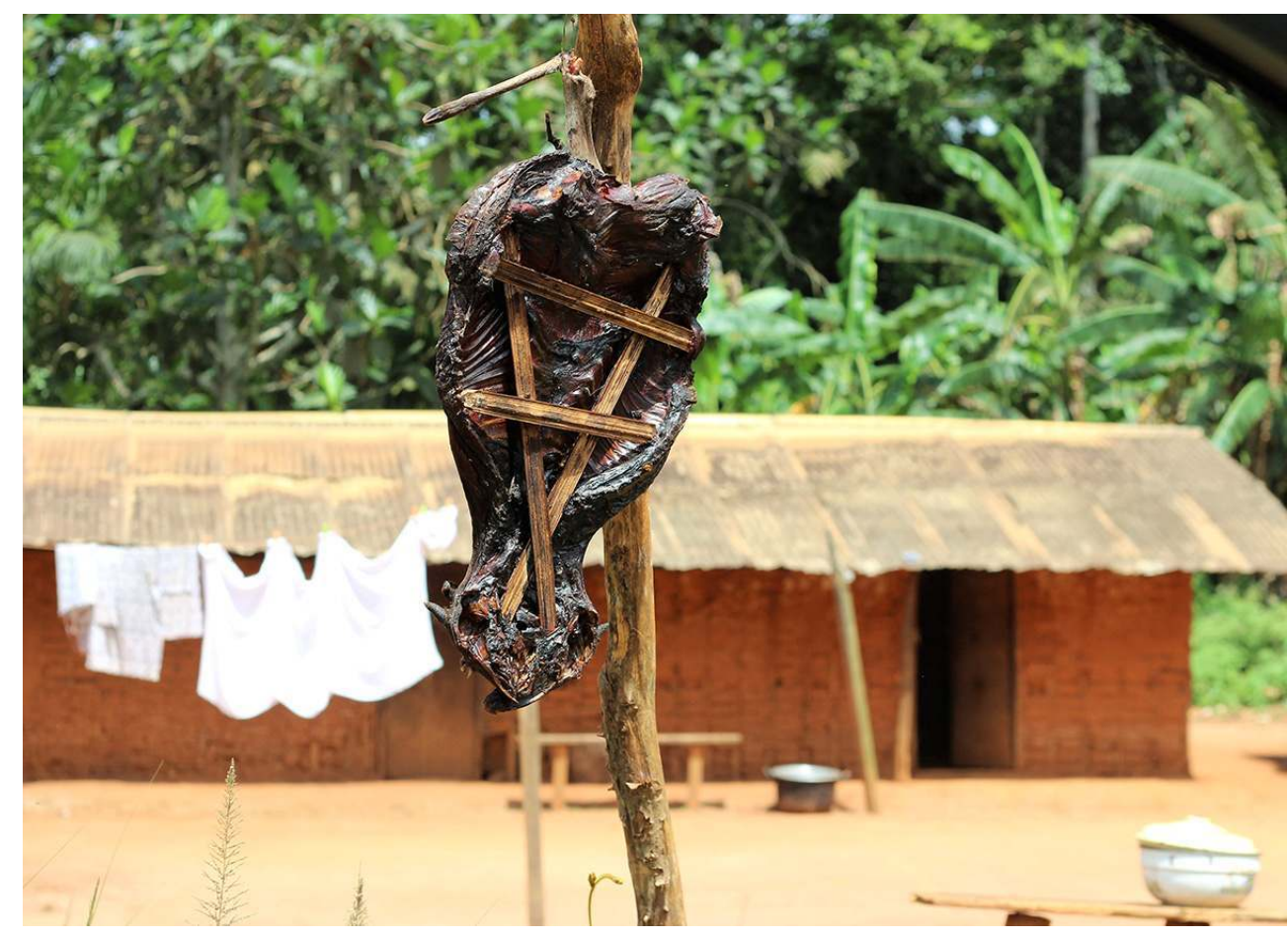

(c) R. Duda

\section{Conclusion}

Among the Baka, wild meat is intimately embedded in cultural representations. Being replete of bushmeat provides strength and joy, fair meat sharing create social cohesion, while meat selling generates income in absence of other alternatives. Understanding how the Baka perceive animals and the local rules governing their consumption also gives information about the Baka system of norms and morality, defining what is good or not for both individual wellbeing and group cohesion. Bushmeat consumption also affects wellbeing as eating a particular species at a specific moment might be considered as posing a threat to the household health. The Baka believe that illnesses might be caused by meat ingestion through the transmission of strength, either bad or good. The emergence of illness might be a sign that something went wrong in the social life and the concept of kilà gives to this a practical and symbolic explanation. The resulting meat avoidances give rich information on the human-animal relations, and ontological differences and proximities: each species, human or animal, has its own kilà, that characterises and regulates its interaction with other species.

This study suggests that the diversity of situations of meat avoidance is adaptive according to individuals and their situation. Meat avoidances seem however to have little effect on Baka diet. Indeed, as already mentioned by Ichikawa (2007), although the different forms of avoidance concern a very wide diversity of species, they refer mostly to "secondary" species, as most species hunted and eaten belong to a small number of species with few negative representations and potential harmful effects. 

mammals that are easily found near villages surroundings (see also Duda et al. 2017). Despite the place in food preferences and their cultural importance in the representation of hunting, large species almost never appeared in the consumption reports. In fact, the rich system of representations and knowledge about animals presented here was developed in a context of abundance and diversity of wildlife, and of relative freedom of movement in the forest. Although human-animals interactions have doubtless always changed through time, external drivers, either pushing or preventing to hunt, show nowadays how the Baka endure cascade effects of globalized policies, which will supposedly lower interactions with animals. A more sedentary lifestyle, increasing incentives for commercialization, the current biodiversity decline, combined with the restriction of uses and movement imposed by conservation policies and the fear of antipoaching patrols known as abusive (Duda \& Gallois, in press) are indeed factors that converge to affect the current place of wild meat in Baka diet, their nutritional status and health condition, their wellbeing through their feelings of protection, and finally their cultural identity.

For a recent example, a ban on the sale of ammunitions and firearms in six regions of the north-western part of the country (due to national conflicts) in April 2018 seems to have critically lower the access to these materials in the southeast, pushing people to engage more with metal-wire trapping. If it would be interesting to estimate positive or negative consequences in terms of wildlife depletion, the Baka already feel a substantial effect on the scarcity of meat in their diet (S. Gallois's field observations, November 2018). On all these aspects, complementary studies would be helpful to better understand the effects of current wildlife depletion on the way the Baka relate to the forest at ontological level.

Moreover, meat selling has become a critical component of Baka economy; being nowadays the product they most often sell to acquire cash. Although the sale of meat and other wild products is not a new phenomenon for the Baka, who have a long history of trading exchanges, meat selling is often the easiest way to satisfy one-time or occasional needs for many households, a fact that the wildlife conservation policies often overlooks in the balance between conservation needs and local people needs. However, the extent of bushmeat commercialization raises the question to what point is the sale of bushmeat done at the expense of the household's own diet, quality of life, maintenance of social capital through sharing, and psychosocial wellbeing. In absence of other economic alternatives, the Baka expose themselves, by selling bushmeat, both to being cheated by buyers and to be considered as poachers and easy targets by eco-guards. In brief, by looking at the importance of wildlife in Baka diet and representations, this study raises multiple questions about the current and coming situation of the Baka, which seemed threatened by multiple factors. Baka knowledge about the forest is today either neglected by wildlife conservation organizations or mobilized by other actors for a bushmeat economy from which they benefit little. Therefore, the Baka appear once again as the first suppliers of a system, but also the first losers.

\section{Acknowledgments}

The research leading to these results was funded by the European Research Council under the European Union's Seventh Framework Program (FP7/2007-2013) / ERC grant agreement $n^{\circ}$ FP7-261971-LEK. We would like to thank Pr. Serge Bahuchet and Pr. Doyle McKey for comments to early versions of this paper. We thank Ernest Simpoh and Appolinaire Ambassa for their assistance with data collection and their friendship. Our deepest thanks go to all the Baka people, women, men 
and children with whom we have shared our lives during this long-term journey in Southeastern Cameroon. We thank them for trusting us, for their patience and understanding, and for all these unforgettable moments of life.

\section{BIBLIOGRAPHY}

Allebone-Webb S. 2008 - Evaluating dependence on wild foods in continental Equatorial Guinea. PhD dissertation, Imperial College London and Institute of Zoology, Zoological Society of London, 291 p.

Bahuchet S. 1985 - Les Pygmées Aka et la foret Centrafricaine : ethnologie écologique. Paris: Société d'Études Linguistiques et Anthropologiques de France.

Bahuchet S. 1988 - Food supply uncertainty among the Aka Pygmies (Lobaye, C.A.R.). In : Garine I. (de) \& Harrison G.A. (Ed.) Coping with Uncertainty in food supply. Clarenton, Oxford University Press : 118-149.

Bahuchet S. 1990 - Food sharing among the Pygmies of central Africa. African Study Monographs 11 (1) : 27-53.

Bahuchet S. 1991 - Les Pygmées d'aujourd'hui en Afrique centrale. Journal des Africanistes 61 (1) : 5-35.

Bahuchet S. 1992 - Dans la forêt d'Afrique Centrale. Les pygmées Aka et Baka. Paris-Louvain, PeetersSelaf, 423 p.

Bahuchet S. 2000 - La filière "viande de brousse". In : Bahuchet S. (Ed.) Les Peuples des forêts tropicales aujourd'hui : volume II, Une approche thématique. Commission européenne, APFT : 331-363.

Bahuchet S. \& Ioveva C. - 1999. De la forêt au marché : le commerce de gibier au sud Cameroun. In : Bahuchet S., Bley D., Pagezy H. \& Vernazza-Licht N. (Ed.) L'Homme et la forêt tropicale. Marseille, Société d'écologie humaine : 533-558.

Bennett E.L. \& Robinson J.G. 2000 - Hunting of wildlife in tropical forests: implications for biodiversity and forest peoples. Washington, D.C., The World Bank, 56 p. (Environment Department working papers ; 76. Biodiversity series).

Bobo K.S., Kamgaing T.O.W., Ntumwel B.C., Kagalang D., Kengne P.N.J., Ndengue S.M.L., Badjeck M.M.N. \& Aghomo F.F.M. 2014 - Species richness, spatial distributions and densities of large and medium-sized mammals in the northern periphery of Boumba-Bek National Park, southeastern Cameroon. African Study Monographs, suppl. 49 : 91-114.

Brisson R. 2010 - Petit dictionnaire Baka-Français, Sud Cameroun. Paris, L'Harmattan, 640 p.

Cawthorn D.-M. \& Hoffman L.C. 2015 - The bushmeat and food security nexus: a global account of the contributions, conundrums and ethical collisions. Food Research International 76 : 906-925.

Coad L., Abernethy K., Balmford A., Manica A., Airy L \& Milner-Gulland E. J. 2010 - Distribution and use of income from bushmeat in a rural village, central Gabon. Conservation Biology 24 (6) :1510-1518. 
Dounias E. 1987 - Ethno écologie et alimentation des Pygmées BaGyeli, Sud-Cameroun. Le Havre : Institut Supérieur Technique d'Outre-Mer, rapport de stage.

Dounias E. 2001 - The management of wild yam tubers by the Baka Pygmies in Southern Cameroon. African Study Monographs 26 : 135-156.

Dounias E. 2016 - From subsistence to commercial hunting: technical shift in cynegetic practices among southern Cameroon forest dwellers during the 20th century. Ecology and Society 21 (1) : 23.

Dounias E. \& Froment A. 2011 - From foraging to farming among present-day forest huntergatherers: consequences on diet and health. International Forestry Review 13 (3) : 294-304.

Duda R. 2017 - Ethnoecology of hunting in an empty forest. Practices, local perceptions and social change about the Baka (Cameroon). PhD dissertation. Universitat Autònoma de Barcelona, Barcelona, 299 p.

Duda R. \& Gallois S. in press - Chasse, déclin de la faune et politiques de conservation au sud-est Cameroun : savoirs et perceptions des Baka. In : Kulesza P. \& Robillard M. (Ed.), Quel avenir pour les Pygmées à l'orée du 21ème siècle ? Qui sont ils ? Ce qu'ils subissent. Comment font-ils face ?. Paris, GITPA/ L'Harmattan : 203-216.

Duda R., Gallois S. \& Reyes-García V. 2017 - Hunting techniques, wildlife offtake and market integration. A perspective from individual variations among the Baka (Cameroon). African Study Monographs 38 (2) : 97-118.

Epelboin A., Bahuchet S. \& Durand J.-L. 2012 - Le bon goût de la viande de primate : des interdits des Pygmées aka aux injonctions écologiques. In : Cros M., Bondaz J. \& Michaud M. (Ed.), L'animal cannibalisé. Festins d'Afrique. Paris, Editions des archives contemporaines : 45-69.

Fa J.E. \& Brown D. 2009 - Impacts of hunting on mammals in African tropical moist forests: a review and synthesis. Mammal Review 39 : 231-264.

Fa J.E., Olivero J., Farfan M.A., Marquez A.L., Duarte J., Nackoney J., Hall, A. Dupain J., Seymour S. \& Johnson P.J. 2015 - Correlates of bushmeat in markets and depletion of wildlife. Conservation Biology 29 : 805-815.

Fargeot C. 2013 - La chasse commerciale en Afrique centrale : une menace pour la biodiversité ou une activité économique durable? Le cas de la République Centrafricaine. $\mathrm{PhD}$ dissertation, Géographie et aménagement de l'espace, Université Paul Valéry, Montpellier, 3 vol., 605 p., 120 p., 82 p.

Froment A., Garine I. (de), Binam Bikoi C. \& Loung J. F. (Ed.) 1996 - Bien manger et bien vivre: anthropologie alimentaire et développement en Afrique intertropicale $: d u$ biologique au social. Paris, L'Harmattan, ORSTOM, 520 p.

Gallois S. 2015 - Dynamics of Local ecological knowledge among the Baka children from southeastern Cameroon. PhD dissertation, Universitat Autònoma de Barcelona, 377 p.

Gallois S. \& Duda R. 2016 - Beyond Productivity: Socio-cultural role of fishing among the Baka of southeastern Cameroon. Revue d'Ethnoécologie. 10, [En ligne] URL https:// ethnoecologie.revues.org/2818 (consulté le 14 décembre 2016).

Gallois S., Lubbers M.J., Hewlett B. \& Reyes-García V. 2018 - Social Networks and Knowledge Transmission Strategies among Baka Children, Southeastern Cameroon. Human Nature 29 (4): 442-463.

Garine I. (de) \& Hladik C.M. 1989 - Les conceptions nutritionnelles : interdits, prescriptions et perception des aliments. In : Hladik C.M., Bahuchet S. \& Garine I. (de) (Ed.), Se nourrir en forêt équatoriale: Anthropologie alimentaire des populations des régions forestières humides d'Afrique. Paris, Unesco : 92-94. 
Garine I. (de) \& Pagezy H. 1990 - Seasonal hunger or « craving for meat ». In : Hladik C.M., Bahuchet S., \& Garine I. (de) (Ed.), Food and nutrition in the African rainforest. Paris: United Nations Educational, Scientific and Cultural Organization Man and the Bioshpere Program : 43-44.

Giles-Vernick T. \& Rupp S. 2006 - Visions of apes, reflections on change: Telling tales of great apes in Equatorial Africa. African Studies Review 49 (1) : 51-73.

Hayashi K. 2008 - Hunting Activities in Forest Camps among the Baka Hunter-gatherers of Southeastern Cameroon. African Study Monographs 29 : 73-92.

Ichikawa M. 1987 - Food restrictions of the Mbuti Pygmies, eastern Zaire. African study monographs, suppl. $6: 97-121$

Ichikawa M. 2007 - Animal food avoidance among Central African hunter-gatherers. In : Dounias E., Motte-Florac E. \& Dunham M. (Ed.), Animal symbolism Animals, keystone in the relationship between man and nature? Paris, IRD : 913-937.

Ichikawa M., Hattori S. \& Yasuoka H. 2016 - Bushmeat Crisis, Forestry Reforms and Contemporary Hunting Among Central African Forest Hunters. In : Reyes-García V. \& Pyhälä A. (Ed.), Hunter-gatherers in a changing world. New-York, Springer : 59-75.

Joiris D. 1996 - Ce que bien manger veut dire chez les Pygmées Kola (Gyeli) et Baka du SudCameroun. In : Froment A., Garine I. (de), Binam Bikoi C. \& Loung J. F. (Ed.). Bien manger et bien vivre. Anthropologie alimentaire et développement en Afrique intertropicale: du biologique au social. Paris, L'Harmattan, ORSTOM, $520 \mathrm{p}$.

Joiris D.V. 1998 - La chasse, la chance, le chant. Aspects du système rituel des Baka du Cameroun. PhD dissertation, Faculté des sciences sociales, politiques et économiques, Université Libre de Bruxelles.

Kimura D., Yasuoka H. \& Furuichi T. 2012 - Diachronic changes in protein acquisition among the Bongando in the Democratic Republic of the Congo. African Study Monographs, suppl. 43:161-178.

Kitanishi K. 2003 - Cultivation by the Baka hunter-gatherers in the tropical rain forest of central Africa. African Study Monographs, suppl. 28 : 143-157.

Kitanishi K. 2006 - The impact of cash and commoditization on the Baka hunter-gatherer society in southeastern Cameroon. African Study Monographs, suppl. 33 : 121-142.

Köhler A. 2000 - Half-man, half-elephant: Shapeshifting among the Baka of Congo. In : Knight J. (Ed.) Natural Enemies People-wildlife Conflicts in Anthropological Perspective. London, Routledge : 50-77.

Köhler A. 2005 - Of apes and men: Baka and Bantu attitudes to wildlife and the making of ecogoodies and baddies. Conservation and Society 3 (2) : 407-435.

Koppert G., Dounias E., Froment A, Pasquet P. 1996 - Consommation alimentaire dans trois populations forestières de la région côtière du Cameroun: Yassa, Mvae et Bakola. In : Hladik C.M., Hladik A., Pagezy H., Linares O.F., Koppert G.J.A. \& Froment A. (Ed.), L'alimentation en forêt tropicale; interactions bioculturelles et perspectives de développement. Paris, Unesco-MAB : 477-496.

Kümpel N.F., East T., Keylock N., Rowcliffe J.M., Cowlishaw G., \& Milner-Gulland E.J. 2007 - De terminants of Bushmeat Consumption and Trade in Continental Equatorial Guinea: an UrbanRural Comparison. In : Davies G. \& Brown D. (Ed.), Bushmeat and Livelihoods: Wildlife Management and Poverty Reduction.Oxford, Blackwell Publishing : 73-91. 
Leclerc C. 2006 - Le retour de chasse : avènement de la jalousie chez les Baka et dynamique sociale (Cameroun). Colloque La chasse : pratiques sociales et symbolique, maison René Ginouvès, archéologie et ethnologie, 9 au 11 juin $2005: 121-132$.

Leclerc C. 2012 - L'adoption de l'agriculture chez les Pygmées baka du Cameroun, dynamique sociale et continuité structurale. Paris,Quae/MSH, $244 \mathrm{p}$.

Lévi-Strauss C. 1962 - La pensée sauvage. Paris, Plon, 347 p.

Lewis J. 2008 - Ekila: blood, bodies, and egalitarian societies. Journal of the Royal Anthropological Institute 14 (2) : 297-315.

Motte-Florac E., Bahuchet S., Thomas J.M.C. \& Epelboin A. 1996 - Place de l'alimentation dans la thérapeutique des Pygmées Aka de Centrafrique. In : Hladik C.M., Hladik A., Pagezy H., Linares O.F., Koppert G.J.A. \& Froment A. (Ed.), L'alimentation en forêt tropicale; interactions bioculturelles et perspectives de développement. Paris, Unesco-MAB : 835-856.

Nasi R., Brown D., Wilkie D., Bennett E., Tutin C., Van Tol G. \& Christophersen T. 2008 - C onservation and use of wildlife-based resources: the bushmeat crisis. Montreal and Bogor, Secretariat of the Convention on Biological Diversity and Center for International Forestry Research (CIFOR). (Technical Series ; $33: 50$ ).

Nasi R., Taber A. \& Van Vliet N. 2011 - Empty forests, empty stomachs? Bushmeat and livelihoods in the Congo and Amazon Basins. International Forestry Review 13 (3) : 355-368.

Oishi T. 2013 - Human-gorilla and gorilla-human: dynamics of human-animal boundaries and interethnic relationships in the central African rainforest. Revue de Primatologie 5, [En ligne] URL : http://journals.openedition.org/primatologie/1881. Consulté le 12 avril 2017.

Oishi T. 2014 - Sharing hunger and sharing food: Staple food procurement in long-term fishing expeditions of Bakwele horticulturalists in southeastern Cameroon. African Study Monographs, Suppl. 47 : 59-72.

Oishi T. \& Hayashi K. 2014 - From ritual dance to disco: Change in habitual use of tobacco and alcohol among the Baka hunter-gatherers of Southeastern Cameroon. Africa Study Monographs 47 : 143-163.

Pagezy H. 1982 - Seasonal hunger, as experienced by the Oto and the Twa of a Ntomba village in the equatorial forest (Lake Tumba, Zaire). Ecology of Food and Nutrition 12 (3) : 139-153.

Puri R.K. \& Vogl C.R. 2005 - A methods manual for ethnobiological research and cultural domain analysis with analysis using ANTHROPAC. Course Manual. Canterbury, UK: Anthropology Department, University of Kent.

Pyhälä A., Osuna Orozco A. \& Counsell S. 2016 - Protected areas in the Congo Basin: Failing both people and biodiversity? London, Rainforest Foundation UK, $144 \mathrm{p}$.

Reyes-García V., Gallois S., Díaz-reviriego I., Fernández-Llamazares Á., Napitupulu L. 2018 - Dietary Patterns of Children on Three Indigenous Societies. Journal of Ethnobiology 38 (2) : 244-260.

Reyes-García V., Powell B., Díaz-Reviriego I., Fernández-Llamazares Á., Gallois S. \& Gueze M. Diet of three remote indigenous populations in a context of changing market participation. Food Security. In press.

Sato H. 1998 - Folk etiology among the Baka, a group of hunter-gatherers in the African rainforest. African Study Monographs, suppl. 25 (33) : 33-46. 
Sperber D. 1975 - Pourquoi les animaux parfaits, les hybrides et les monstres sont-ils bons à penser symboliquement? L'Homme 15 (2) : 5-34.

Takeuchi K. 2013 - Inter-ethnic relations between Pygmies and farmers. In : Hewlett B. (Ed.) Hunter-Gatherers of the Congo Basin: Culture, History and Biology of African Pygmies. New Brunswick, New Jersey and London, Transaction Publishers : 299-320.

Terashima H. 2001 - The relationships among plants, animals and man in the african tropical rain forest. African Study Monographs 27 : 43-60.

Thomas J.M.C, Bahuchet S., Epelboin A., \& Fürniss S. 1981- 2014 - Encyclopédie des Pygmees Aka: techniques, language et société des chasseurs-cueilleurs de la forêt centraficaine (Sud-Centrafrique et Nord Congo). Paris, Editions Peeters-SELAF, 11 volumes, 3130 p.

Townsend C. 2015 - Baka ritual flow diverted. Hunter-Gatherer Research 1 (2) : 197-224.

Turnbull C. 1965 - Waywards servants: The two worlds of the african Pygmies. New York, The Natural History Press, $392 \mathrm{p}$.

Van Vliet N. \& Mbazza P. 2011 - Recognizing the multiple reasons for bushmeat consumption in urban areas: A necessary step toward the Sustainable use of wildlife for food in Central Africa. Human Dimensions of Wildlife 16 : 45-54.

Van Vliet N., Milner-Gulland E.J., Bousquet F., Saqalli M. \& Nasi R. 2010 - Effect of small-scale heterogeneity of prey and hunter distributions on the sustainability of bushmeat hunting. Conservation Biology 24 : 1327-1337.

Van Vliet N., Moreno J., Gómez J., Zhou W., Fa J.E., Golden C., Alves R.R.N., \& Nasi R. 2017 Bushmeat and human health: Assessing the evidence in tropical and sub-tropical forests. Ethnobiology and Conservation $6: 3$.

Yasuoka H. 2009 - The variety of forest vegetations in southeastern Cameroon, with special reference to the availability of wild yams for the forest hunter-gatherers. African Studies Monographs 30 : 89-119.

Yasuoka H. 2014 - Snare hunting among Baka hunter-gatherers: implications for sustainable wildlife management. African Study Monographs, suppl. 49 : 115-136.

\section{NOTES}

1. The similar term kilà is used in baka langage but without the bantou prefix, the baka being an ubanguian langage. A second term mokindà is also reported by Brisson (2010).

2. We choose to use food "avoidances" rather than food "proscription" or "prohibition", as in this context kìlà relates more on personal decisions to not consume some foods to avoid a specific consequence, and depending on personal and familial history. The terms proscriptions or prohibitions would imply a practice resulting on social pressures and equally adopted within the community.

3. See video from R. Duda : Digging out the porcupine, Baka chronicles June 2013. https://www.canalu.tv/video/smm/dl.1/podcast.1/

unearthing_the_porcupine_a_hunting_party_between_brothers_chronicle_baka_district_of_messok_east_cameroon_june_2013.46841

4. Scientific and vernacular names of all animal and plant species in the text are all resumed in the figure 3 .

5. Original question: na kàmbia so, nga mò, mo ndé a jò ?

6. Original question: na kàmbia so, nga mò, mo a yé $a$ jò ? 
7. See videos related to meat consumption https://www.canal-u.tv/auteurs/duda_romain/ videos\#element_2

8. Meat bought and monkeys (often reported under the categoric name kémà) were difficult to identify at the species level.

9. About animals' reactions to menstrual smell and blood symbolism see Lewis (2008).

10. For a deeper insight on è.kìlà among the Aka of Congo in relation with gendered production and reproductive life see Lewis (2008).

11. In parallel, the mythical animals, are in Baka thought precisely hybrids. This is especially the case of the yoli, a mythical serpent attacking humans with the aid of a bee's sting, bearing a cock's crest and living near the water.

12. Pigs are said to have first benne brought into the Messok district in 1963-1964 by a clerk coming from Abong-Mbang.

13. To celebrate the authors' returns or visits to forest camps, a hen was sometimes specially killed for the meal, but they often remained the only ones to eat some.

14. Obviously, some patrilineages are more represented in certain areas than others.

15. Mouse species have not been determined and are included here as a one category.

16. Arboreal monkeys have been aggregated as some observations could not be identified to the species level.

17. However, the contribution of ivory is both underestimated and disproportionate compared to occasional sales of pangolin scales, sold - since the years 2010 s - at 1.000 francs CFA (1 liter pot) as a side-product.

18. For the scope of this section, and to better estimate the sale of game we did not count the game killed in the context of hunting "job" (i.e. hunting activity against wage and firearm lending), as it is a wage labor rather than a real trading activity, although this leads to an underestimation of the quantities harvested.

19. Observations made for the average household size, composed by 3 adults and 4-5 children.

\section{ABSTRACTS}

In the Congo Basin, food is an everyday concern and its acquisition and transformation often structure many of the activities of a human group. While agriculture provides the main source of calories, meat of wild animals, commonly referred to as bushmeat, represents the main source of protein for local people in the region and plays an important role in terms of dietary diversity and health. However, the increase of bushmeat consumption in towns and more efficient hunting practices have pushed the harvest of wild animals to unsustainable levels, generating a "bushmeat crisis". The growing demand for bushmeat has created strong pressures and a lure of profit pushing the hunters of southern Cameroon to sell (illegally) their harvest. A dynamic that might affect both local diets and the modalities of relations between humans and animals. Therefore, this paper aims to describe the importance of wild meat for the Baka, an ethnolinguistic group of Southeastern Cameroun, traditionally hunter-gatherers. It analyses the place of the animal in the Baka daily life through its contribution in dietary, symbolic and economic terms. The paper combines a qualitative ethnography with individual-level data on food diversity intake and meat selling, and describes different aspects related to meat sharing and consumption. 
Dans le bassin du Congo, l'alimentation est une préoccupation quotidienne et son acquisition et sa transformation structurent souvent bon nombre des activités humaines. Alors que l'agriculture fournit la principale source de calories, la viande d'animaux sauvages, communément appelée viande de brousse, représente la principale source de protéines pour les populations locales et joue un rôle important en termes de diversité alimentaire et de santé. Cependant, l'augmentation de la consommation de viande sauvage en villes et des pratiques de chasse plus efficaces ont poussé la capture d'animaux sauvages à des niveaux non durables, générant une "crise de la viande de brousse». Cette demande croissante a engendré de fortes pressions et un attrait financier qui pousse les chasseurs du sud du Cameroun à commercialiser (illégalement) leur gibier. Une dynamique qui pourrait affecter le régime alimentaire local, mais aussi les modalités de relations entre humains et animaux, intimement liées à des représentations du bien-être, de cohésion sociale et à l'identité culturelle. Cet article décrit l'importance de l'animal-gibier pour les Baka, une société du sud-est Cameroun, historiquement chasseurs-cueilleurs. Il analyse la place actuelle de l'animal-gibier dans le quotidien des Baka à travers sa contribution alimentaire, symbolique et économique. L'étude combine une ethnographie qualitative avec des données individuelles de consommation et de vente de gibier, et décrit différents aspects liés au partage et à la consommation de viande.

\section{INDEX}

Geographical index: Cameroun

Keywords: wild meat, hunter-gatherers, pygmies, diet, food avoidances, anthropology of food

Mots-clés: viande sauvage, faune sauvage, chasseurs-cueilleurs, pygmées, régime alimentaire, évitements alimentaires, anthropologie de l'alimentation

\section{AUTHORS}

\section{ROMAIN DUDA}

Unité d'Épidémiologie des maladies émergentes, Institut Pasteur, 25-28 rue du Dr. Roux, 75015 Paris, France

Laboratoire Eco-anthropologie \& Ethnobiologie, Muséum national d'Histoire naturelle, Site du Musée de l'Homme, Paris, France

romain.duda@pasteur.fr

\section{SANDRINE GALLOIS}

Laboratoire Eco-anthropologie \& Ethnobiologie, Muséum national d'Histoire naturelle, Site du Musée de l'Homme, Paris, France

Faculty of Archaeology, Leiden University, Netherlands

\section{VICTORIA REYES-GARCÍA}

Institut de Ciència i Tecnologia Ambientals, Universitat Autònoma de Barcelona, 08193Bellaterra, Spain

Institució Catalana de Recerca i Estudis Avançats, Pg. Lluís Companys 23, 08010 Barcelona,Spain 